Article

\title{
A Versatile Strategy for the Synthesis of 4,5-Dihydroxy-2,3-Pentanedione (DPD) and Related Compounds as Potential Modulators of Bacterial Quorum Sensing
}

\author{
Silvia Stotani ${ }^{1,2}$, Viviana Gatta ${ }^{3}$, Federico Medda ${ }^{1,+}$, , Mohan Padmanaban ${ }^{1}$, \\ Anna Karawajczyk ${ }^{1, \ddagger}$, Päivi Tammela ${ }^{3}{ }^{\mathbb{C}}$, Fabrizio Giordanetto ${ }^{1, \S}$, Dimitrios Tzalis ${ }^{1}$ \\ and Simona Collina $2, *$ (D) \\ 1 Medicinal Chemistry, Taros Chemicals GmbH \& Co. KG, Emil-Figge-Straße 76a, 44227 Dortmund, Germany; \\ silviastotani@hotmail.it (S.S.); fmedda@centurionbiopharma.com (F.M.); mpadmanaban@taros.de (M.P.); \\ akarawajczyk@gmail.com (A.K.); Fabrizio.Giordanetto@deshawresearch.com (F.G.); dtzalis@taros.de (D.T.) \\ 2 Department of Drug Sciences, Medicinal Chemistry and Pharmaceutical Technology Section, University of \\ Pavia, Viale Taramelli 12, 27100 Pavia, Italy \\ 3 Drug Research Program, Division of Pharmaceutical Biosciences, Faculty of Pharmacy, University of \\ Helsinki, FI-00014 Helsinki, Finland; viviana.gatta@helsinki.fi (V.G.); paivi.tammela@helsinki.fi (P.T.) \\ * Correspondence: simona.collina@unipv.it; Tel.: +39-0382-987379 \\ + Current address: Centurion Biopharma Corporation, Engesserstraße 4, 79108 Freiburg im \\ Breisgau, Germany. \\ $\ddagger$ Current address: Selvita S.A., Park Life Science, Bobrzyňskiego 14, 30-348 Krakow, Poland.
}

Received: 16 September 2018; Accepted: 3 October 2018; Published: 6 October 2018

\begin{abstract}
Resistance to antibiotics is an increasingly serious threat to global public health and its management translates to significant health care costs. The validation of new Gram-negative antibacterial targets as sources for potential new antibiotics remains a challenge for all the scientists working in this field. The interference with bacterial Quorum Sensing (QS) mechanisms represents a potentially interesting approach to control bacterial growth and pursue the next generation of antimicrobials. In this context, our research is focused on the discovery of novel compounds structurally related to (S)-4,5-dihydroxy-2,3-pentanedione, commonly known as (S)-DPD, a small signaling molecule able to modulate bacterial QS in both Gram-negative and Gram-positive bacteria. In this study, a practical and versatile synthesis of racemic DPD is presented. Compared to previously reported syntheses, the proposed strategy is short and robust: it requires only one purification step and avoids the use of expensive or hazardous starting materials as well as the use of specific equipment. It is therefore well suited to the synthesis of derivatives for pharmaceutical research, as demonstrated by four series of novel DPD-related compounds described herein.
\end{abstract}

Keywords: antibiotic resistance; quorum sensing; DPD; DPD-related compounds

\section{Introduction}

Bacterial chemical communication (i.e., quorum sensing, QS) allows bacteria to coordinate their gene expression and act as a population [1-5]. This phenomenon is detrimental for humans as QS regulates pathogenic processes such as the virulence factor production [6,7], susceptibility to antibiotics [8] and biofilm formation [9-11]. In recent decades, the modulation of QS has therefore emerged as a potential therapeutic approach to fight bacterial infections [12-17].

QS is mediated by production and release of and response to small molecules called autoinducers (AIs). Among these AIs, Autoinducer-2 (AI-2) is responsible for intra- and interspecies 
bacterial communication and, as a consequence, it has been termed the "universal autoinducer". The development of small molecules able to modulate the AI-2-mediated signaling would possibly result in broad-spectrum antimicrobial activity. However, targeting the AI-2-based QS remains challenging mostly because of the rapid interconversion of the AI-2 precursor (S)-DPD (Figure 1) to several linear and cyclic forms recognized by different bacteria [18] (Figure 1). In aqueous solutions, (S)-DPD is in equilibrium with its two cyclic stereoisomers (S-DHMF and R-DHMF; Figure 1) [19]. Hydration of the $C_{3}$ carbonyl group of both the cyclic and linear structures was confirmed by $X$-ray crystallography. In the presence of boric acid, S-THMF (Figure 1) forms a borate ester (S-THMF-borate; Figure 1) which is recognized by LuxP in $V$. harveyi (PDB ID: 1JX6) [20]. $R$-THMF instead (Figure 1) does not coordinate boron and binds to the transporter LsrB which is responsible for its internalization and acts as the active species in S. thyphimurium AI-2-mediated QS (PDB ID: 1TJY) [21]. The hydrated form of linear (S)-DPD (S-THP, Figure 1) is phosphorylated by LsrK, resulting in phospho-DPD (P-DPD, Figure 1) [22] recognized by the transcriptional repressor LsrR (PDB ID: 4L4Z) [23] and responsible for E coli and S. typhimurium AI-2-mediated signaling.

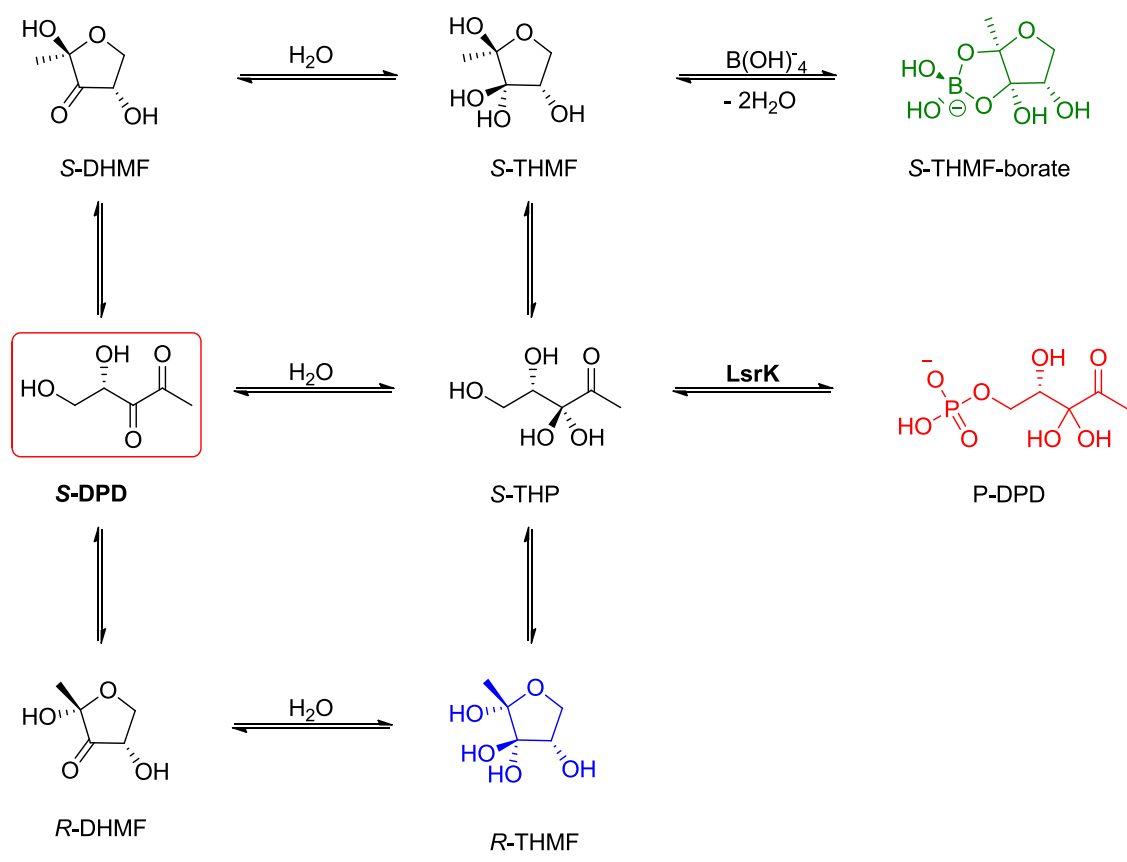

Figure 1. (S)-DPD in an aqueous medium: all species in equilibrium. (2S,4S)-2,4-dihydroxy-2methyldihydrofuran-3-one (S-DHMF); (S)-4,5-dihydroxy-2,3-pentanedione (DPD); (2R,4S)-2,4dihydroxy-2-methyldihydrofuran-3-one $\quad(R$-DHMF); $\quad(2 S, 4 S)$-2-methyl-2,3,3,4tetrahydroxytetrahydrofuran (S THMF); (S)-3,3,4,5-tetrahydroxy-2-pentanone (S-THP); $\quad(2 R, 4 S)-2-m e t h y l-2,3,3,4-\quad$ tetrahydroxytetrahydrofuran $\quad(R$-THMF); $\quad(2 S, 4 S)-2-$ methyl-2,3,3,4-tetrahydroxytetrahydrofuranborate (S-THMF-borate); $\quad(S)-3,3,4,5-$ tetrahydroxy-2-pentanone-5-phosphate (P-DPD).

Modulation/inhibition of QS can control several bacterial virulence factors (e.g., biofilm formation) that facilitate human infections and reduce their negative effects, including mortality [24]. Quorum Sensing Inhibitors (QSI) therefore represent interesting tools to use in combination with "conventional" antibiotic therapies against antimicrobial resistance (AMR) [25,26].

In this work, we describe the set-up of a new protocol for the synthesis of racemic DPD and its application to the synthesis of four novel small libraries of DPD-related compounds (Figure 2), designed to target LsrK kinase, a key mediator in AI-2-mediated QS in enteric bacteria. The essential role of the enzyme has been demonstrated by LsrK gene deletion in E. coli, generating a mutant strain unable to activate AI-2-mediated QS [27]. Therefore, we believe that the generation of DPD-related 
compounds for the inhibition of LsrK may be the starting point for the development of new QSI that will serve as potential tools for overcoming antimicrobial resistance.

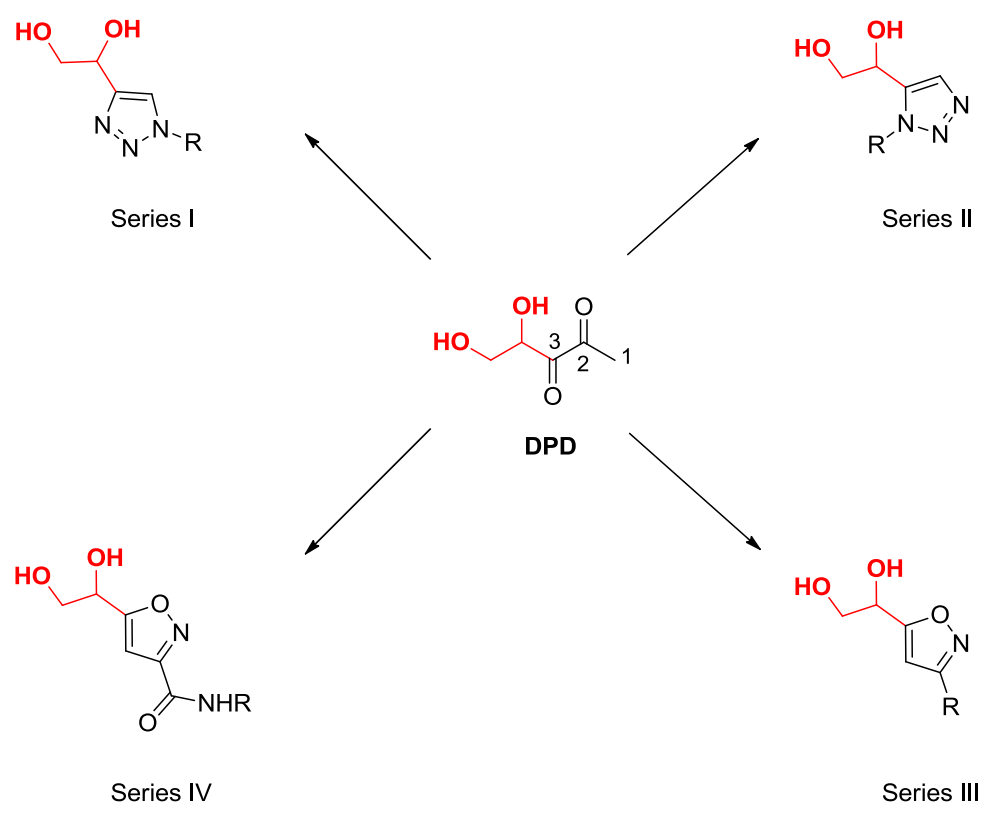

Figure 2. The DPD-related compounds presented in this work.

\section{Results and Discussion}

Since 2004, much effort has been devoted to the study of synthetic pathways for the preparation of DPD and analogs in both racemic and enantiomeric forms. Literature analysis revealed that the synthesis of homochiral DPD requires the use of expensive (i.e., (S)-1,4-dioxaspiro[4.5]decane-2-carboxaldehyde) or unstable (i.e., (S)-glyceraldehyde acetonide) chiral starting materials and of further time-consuming purification steps [18,28-33]. Conversely, the synthetic procedures published so far to obtain racemic DPD proceed smoothly but suffer from hazardous chemical steps (i.e., reductive ozonolysis or the use of diazomethane) [34,35].

Starting from these considerations and keeping in mind that in the initial phase of the drug discovery process racemic compounds are usually evaluated and only once the most active ones have been identified both enantiomers must be prepared for biological testing [36], herein we studied a novel versatile strategy for the synthesis of racemic DPD suitable for readily supporting practical chemical diversification. The proposed synthetic strategy leading to DPD could be useful for the preparation of $\mathrm{C}_{1}$ DPD-analogs and for the synthesis of DPD structurally related compounds, where the two carbonyl groups of DPD at $C_{2}$ and $C_{3}$ are embedded in heteroaromatic rings (Figure 2). To the best of our knowledge, no modification at $C_{2}$ have been reported and position $C_{3}$ has been barely explored and no heteroaromatic substituents (except for a furan at $C_{1}$ ) were previously described.

\subsection{Synthesis of DPD and Ph-DPD}

The synthetic strategies originally evaluated are outlined in Scheme 1. 


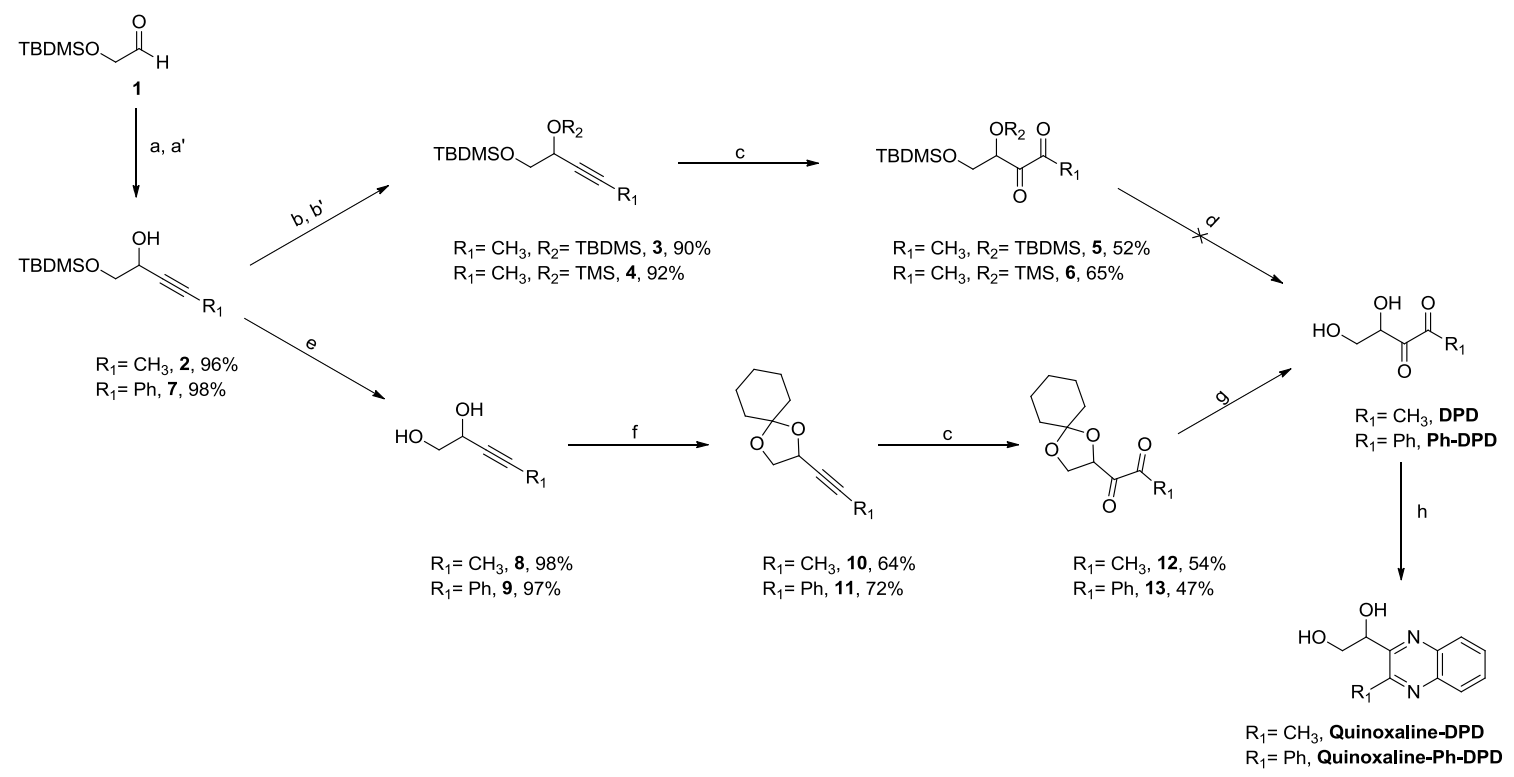

Scheme 1. The synthesis of racemic DPD, Ph-DPD, quinoxaline-DPD and quinoxaline-Ph-DPD. Reagents and conditions: (a) 1-propynylmagnesium bromide $(0.5 \mathrm{M}$ in THF, $1.3 \mathrm{eq}), \mathrm{THF}, 0{ }^{\circ} \mathrm{C}$ to $\mathrm{rt}, 3 \mathrm{~h}$; $\left(\mathrm{a}^{\prime}\right)$ phenylethynylmagnesium bromide $(1.0 \mathrm{M}$ in THF, $1.3 \mathrm{eq}), \mathrm{THF}, 0^{\circ} \mathrm{C}$ to $\mathrm{rt}, 3 \mathrm{~h}$; (b) TBDMSCl (1.2 eq), $\mathrm{NaH}$ (2.0 eq), THF, rt, 3 h; (b') TMSCl (1.2 eq), NaH (2.0 eq), THF, rt, 3 h; (c) $\mathrm{NaIO}_{4}$ (4.4 eq), $\mathrm{Ru}_{2} \mathrm{O} \cdot \mathrm{H}_{2} \mathrm{O}$ (2.5\% mol), $\mathrm{CHCl}_{3} / \mathrm{ACN} / \mathrm{H}_{2} \mathrm{O}$ (1:1:1), rt, 1 h; (d) see Table S1; (e) Dowex50WX8 100-200 mesh, MeOH, rt, overnight; (f) cyclohexanone dimethyl ketal (3.0 eq), p-TSA (cat.), rt, overnight; (g) Dowex50WX8 100-200 mesh, $\mathrm{D}_{2} \mathrm{O}$ (10 mM), rt, overnight; (h) o-phenylendiamine (2.0 eq), rt, overnight.

Briefly, the addition of 1-propynylmagnesium bromide to ( $t$-butyldimethylsilyloxy)acetaldehyde [37] (1, Scheme 1), followed by the protection of the resulting secondary alcohol with TBDMSCl or TMSCl afforded compounds 3 or 4 , respectively (Scheme 1). The subsequent oxidation of the internal alkyne to yield diketone 5 or $\mathbf{6}$ was performed under optimized $\mathrm{RuO}_{2}{ }^{*} \mathrm{H}_{2} \mathrm{O} / \mathrm{NaIO}_{4}$-catalyzed conditions (Table 1, entry 5) using $\mathrm{CHCl}_{3} / \mathrm{ACN} / \mathrm{H}_{2} \mathrm{O}$ (1:1:1) as the solvent.

Table 1. The optimization of the conditions for the oxidation of compound 3. All the reactions were performed at room temperature.

\begin{tabular}{ccccc}
\hline Entry & Solvent & Oxidant and eq & Time & Yield (\%) \\
\hline 1 & Acetone & $\mathrm{KMnO}_{4} / \mathrm{NaHCO}_{3} / \mathrm{MgSO}_{4} 3.8 / 0.6 / 2.0$ & Overnight & No reaction \\
2 & Acetone & $\mathrm{KMnO}_{4} / \mathrm{NaHCO}_{3} / \mathrm{MgSO}_{4} 3.9 / 0.6 / 4.2$ & Overnight & Traces \\
3 & $\mathrm{CCl}_{4} / \mathrm{ACN}(1: 1)$ & $\mathrm{NaIO}_{4} / \mathrm{RuO}_{2} \cdot \mathrm{H}_{2} \mathrm{O}$ & $3 \mathrm{~h}$ & Traces \\
& & $2.2 \mathrm{eq} / 2.5 \% \mathrm{~mol}$ & & \\
4 & $\mathrm{CCl}_{4} / \mathrm{ACN}(1: 1)$ & $\mathrm{NaIO}_{4} / \mathrm{RuO}_{2} \cdot \mathrm{H}_{2} \mathrm{O}$ & $3 \mathrm{~h}$ & 23 \\
& & $4.4 \mathrm{eq} / 2.5 \% \mathrm{~mol}$ & 52 \\
5 & $\mathrm{CHCl}_{3} / \mathrm{ACN} / \mathrm{H}_{2} \mathrm{O}(1: 1: 1)$ & $4.4 \mathrm{eq} / 2.5 \% \mathrm{~mol}$ & $3 \mathrm{~h}$ & $52 \mathrm{Hol}$ \\
\hline
\end{tabular}

The final acidic removal of the two TBDMS groups of compound $\mathbf{5}$ was performed under different conditions, but resulted in being unsuccessful (Table S1). Particularly, decomposition was observed when $\mathrm{H}_{2} \mathrm{SO}_{4}$ (or $\mathrm{D}_{2} \mathrm{SO}_{4}$ ) and TBAF were employed (Table S1). The partial removal of the two protecting groups (up to a maximum of 30\% in total) was achieved with the use of acetic acid or Dowex50WX8 (Table S1). When the bulky protecting TBDMS group was replaced with TMS, (Scheme 1), similar results were obtained and a maximum of $40 \%$ cleavage was achieved using Dowex50WX8 in ACN- $d_{3}$.

A different approach was then investigated: compound $\mathbf{2}$ and the analogous $\mathbf{7}$ were deprotected in acidic conditions (Dowex50WX8), affording diols $\mathbf{8}$ and $\mathbf{9}$, respectively. These intermediates were 
then protected with a cyclohexyliden group and oxidized under the previously described conditions (Table 1). The oxidation of $\mathbf{1 0}$ and $\mathbf{1 1}$ was followed by the Dowex50WX8-mediated removal of the protecting group. ${ }^{1} \mathrm{H}-\mathrm{NMR}$ analysis of the crude products was consistent with the literature-reported data and revealed the presence of a mixture of structures in equilibrium with each other (see SI for additional details). To further confirm the success of our procedure, the mixtures were treated with o-phenilendiamine to form, respectively, quinoxaline-DPD and quinoxaline-Ph-DPD (Scheme 1), which were isolated and fully characterized.

To sum up, the approach described above allows for the rapid production of racemic DPD in five steps and it does not require the use of dangerous or expensive reagents nor of particular equipment (i.e., ozonolysator); furthermore, only one purification step via column chromatography is necessary. Not less important, this procedure is suitable for the synthesis of $\mathrm{C}_{1}$-DPD analogs (as long as the corresponding Grignard reagent can be purchased or produced) as the synthesis of Ph-DPD demonstrated. Additionally, the ethyne function introduced in the first step is a practical synthetic handle for further chemical derivatization, as demonstrated by the four small series of derivatives described below.

\subsection{Synthesis of DPD-Related Compounds}

As anticipated, we designed novel DPD-related compounds in which the carbonyl groups at $C_{2}$ and $C_{3}$ are embedded in heteroaromatic moiety to obtain compounds stable in solution, thus avoiding the open/closed equilibrium typical of the majority of the DPD-analogs reported so far (Figure 1). As heteroaromatic rings, we selected 1,2,3-triazole and isoxazole, two scaffolds common in medicinal chemistry present in several natural and synthetic drugs including antimicrobial, anticancer, anti-inflammatory and antireumatic drugs [38-43].

The newly designed compounds can be obtained starting from the two common intermediates 15 and 16 (Scheme 2) strictly related to 2 and $\mathbf{7}$ (Scheme 1). In details, as in the case of DPD, the first of the two building blocks necessary to start the synthesis of all the analogs presented in this work was produced by the Grignard addition of ethynylmagnesium bromide to aldehyde 1, followed by acidic removal of the TBDMS protecting group. Further protection of the resulting diol $\mathbf{1 5}$ as acetal, using cyclohexanone dimethyl ketal, afforded the second building block compound 16 (Scheme 2).

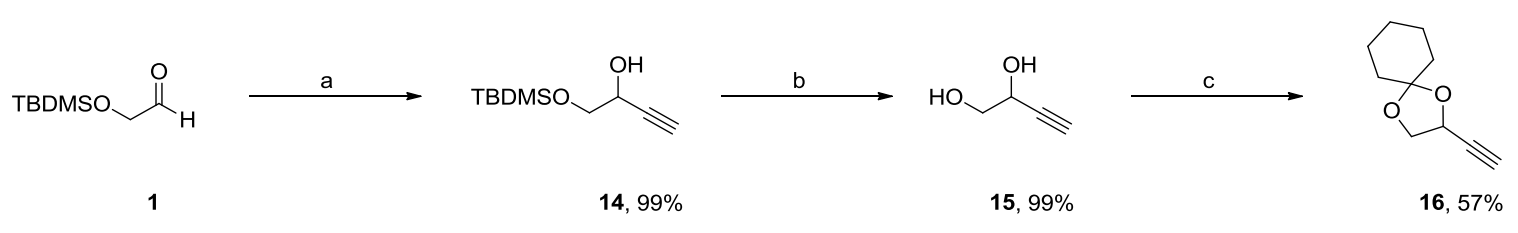

Scheme 2. The synthesis of intermediates 15 and 16. Reagents and conditions: (a) ethynylmagnesium bromide (0.5 M in THF, $1.3 \mathrm{eq}$ ), THF, $0{ }^{\circ} \mathrm{C}$ to rt, 3h; (b) Dowex50WX8 100-200 mesh, MeOH, rt, overnight; (c) cyclohexanone dimethyl ketal (3.0 eq), p-TSA (cat.), rt, overnight.

\subsubsection{1,4- and 1,5-Disubstituted 1,2,3-Triazoles DPD-Derivatives (Series I and II)}

1,2,3-triazoles (both 1,4- and 1,5-disubstituted) can be synthesized applying azide-alkyne Huisgen cycloaddition conditions where an azide is reacted with an alkyne in a 1,3-dipolar cycloaddition reaction. At first, we tested three different Copper-Catalyzed Azide-Alkyne Cycloaddition (CuAAC) conditions to select the best procedure for the synthesis of the planned compounds. For this purpose, (2-azidoethyl)benzene (17a) was chosen as the reference azide (Table 2). First, we used CuI (10\% mol) and DIPEA $(15 \% \mathrm{~mol})$ in nonaqueous, nonprotic THF to afford the desired product with $58 \%$ isolated yield (Table 2, entry 1) [44]. As the addition of $\mathrm{AcOH}$ was found to accelerate the protonation of the $\mathrm{Cu}-\mathrm{C}$ bond [45-47] (thus facilitating the formation of the product), a catalytic amount of $\mathrm{AcOH}$ was added to the mixture (containing $2 \% \mathrm{~mol} \mathrm{CuI} \mathrm{and} 4 \%$ mol DIPEA). This acid-base system jointly promoted CuAAC and resulted in a $14 \%$ increase of the isolated yield (Table 2, entry 2 ) when compared 
to the previous conditions (Table 2, entry 1) [48]. It is known that the use of ligands is beneficial for the reaction as it prevents $\mathrm{Cu}(\mathrm{I})$ oxidation and avoids the use of a base. Therefore, it is not surprising that the in situ generation of $\mathrm{Cu}(\mathrm{I})$ by the reduction of $\mathrm{CuSO}_{4} * 5 \mathrm{H}_{2} \mathrm{O}$ from sodium ascorbate together with the formation of L-ascorbic acid (that acts both as a ligand and as acidic source) raised the yield up to $89 \%$ (Table 2, entry 3) [49]. The 1,4-disubstitution was confirmed by the HMBC of compound 18a (see Supporting Information).

Table 2. The reaction conditions to obtain 18a-f and 19a. All reactions were performed overnight at room temperature except for entry 4 where the mixture was heated at $60^{\circ} \mathrm{C}$.

\begin{tabular}{|c|c|c|c|c|c|c|c|}
\hline & 15 & $17 a-f$ & & $18 a-f$ & & 19a & \\
\hline Entry & $\mathbf{R}_{1}$ & Azide, eq & Solvent & Catalyst & Product & Yield $(\%)^{a}$ & Ref \\
\hline 1 & $\left(\mathrm{CH}_{2}\right)_{2}-\mathrm{Ph}$ & 17a, 1.1 & THF & $\begin{array}{c}\text { CuI }(10 \% \mathrm{~mol}) \\
\text { DIPEA }(15 \% \mathrm{~mol}) \\
\text { CuI }(2 \% \mathrm{~mol})\end{array}$ & $18 a$ & 58 & {$[44]$} \\
\hline 2 & $\left(\mathrm{CH}_{2}\right)_{2}-\mathrm{Ph}$ & 17a, 1.05 & DCM & $\begin{array}{l}\text { DIPEA ( } 4 \% \text { mol) } \\
\text { AcOH (cat) }\end{array}$ & $18 a$ & 72 & {$[48]$} \\
\hline 3 & $\left(\mathrm{CH}_{2}\right)_{2}-\mathrm{Ph}$ & $17 \mathbf{a}, 1.0$ & $\begin{array}{c}t-\mathrm{BuOH} / \mathrm{H}_{2} \mathrm{O} \\
(1: 1)\end{array}$ & $\begin{array}{l}\mathrm{CuSO}_{4} \cdot 5 \mathrm{H}_{2} \mathrm{O}(5 \% \mathrm{~mol}) \\
\text { Na Ascorbate }(0.5 \mathrm{eq})\end{array}$ & $18 a$ & 89 & [49] \\
\hline 4 & $\left(\mathrm{CH}_{2}\right)_{2}-\mathrm{Ph}$ & $17 \mathrm{a}, 1.0$ & 1,4-dioxane & $\left(\mathrm{Cp} * \mathrm{RuCl}\left(\mathrm{PPh}_{3}\right)_{2}\right)(2 \% \mathrm{~mol})$ & $19 a$ & 87 & {$[50]$} \\
\hline 5 & $\left(\mathrm{CH}_{2}\right)-\mathrm{Ph}$ & $17 b, 1.0$ & $\underset{(1: 1)}{t-\mathrm{BuOH} / \mathrm{H}_{2} \mathrm{O}}$ & $\begin{array}{c}\mathrm{CuSO}_{4} \cdot 5 \mathrm{H}_{2} \mathrm{O}(5 \% \mathrm{~mol}) \\
\mathrm{Na} \text { Ascorbate }(0.5 \mathrm{eq})\end{array}$ & $18 b$ & 60 & [49] \\
\hline 6 & $\left(\mathrm{CH}_{2}\right)_{2}-\mathrm{o}-\mathrm{F}-\mathrm{Ph}$ & $17 \mathrm{c}, 1.0$ & $\begin{array}{c}t-\mathrm{BuOH} / \mathrm{H}_{2} \mathrm{O} \\
(1: 1)\end{array}$ & $\begin{array}{l}\mathrm{CuSO}_{4} \cdot 5 \mathrm{H}_{2} \mathrm{O}(5 \% \mathrm{~mol}) \\
\text { Na Ascorbate }(0.5 \mathrm{eq})\end{array}$ & $18 \mathrm{c}$ & 62 & [49] \\
\hline 7 & $\left(\mathrm{CH}_{2}\right)_{2}-m-\mathrm{Pyr}$ & $17 \mathrm{~d}, 1.0$ & $\underset{(1: 1)}{t-\mathrm{BuOH} / \mathrm{H}_{2} \mathrm{O}}$ & $\begin{array}{l}\mathrm{CuSO}_{4} \cdot 5 \mathrm{H}_{2} \mathrm{O}(5 \% \mathrm{~mol}) \\
\text { Na Ascorbate }(0.5 \mathrm{eq})\end{array}$ & $18 \mathrm{~d}$ & 88 & [49] \\
\hline 8 & $\left(\mathrm{CH}_{2}\right)_{5}-\mathrm{CN}$ & $17 \mathbf{e}, 1.0$ & $\underset{(1: 1)}{t-\mathrm{BuOH} / \mathrm{H}_{2} \mathrm{O}}$ & $\begin{array}{l}\mathrm{CuSO}_{4} \cdot 5 \mathrm{H}_{2} \mathrm{O}(5 \% \mathrm{~mol}) \\
\text { Na Ascorbate }(0.5 \mathrm{eq})\end{array}$ & $18 \mathrm{e}$ & 72 & [49] \\
\hline 9 & $\left(\mathrm{CH}_{2}\right)_{2}-\mathrm{CyH}$ & $\mathbf{1 7 f}, 1.0$ & $\begin{array}{c}t-\mathrm{BuOH} / \mathrm{H}_{2} \mathrm{O} \\
(1: 1)\end{array}$ & $\begin{array}{l}\mathrm{CuSO}_{4} \cdot 5 \mathrm{H}_{2} \mathrm{O}(5 \% \mathrm{~mol}) \\
\text { Na Ascorbate }(0.5 \mathrm{eq})\end{array}$ & $18 \mathrm{f}$ & 73 & [49] \\
\hline
\end{tabular}

a Isolated yield.

The corresponding 1,5-disubstituted 1,2,3-triazole 19a was also synthesized by varying the experimental conditions: the regioselective synthesis was achieved with the use of Ruthenium-catalyzed Azide-Alkyne Cycloaddition (RuAAC) conditions. Azide 17a was reacted with terminal alkyne $\mathbf{1 5}$ in the presence of $2 \%$ mol pentamethylcyclopentadienylbis (triphenylphosphine)ruthenium(II) chloride $\left(\mathrm{Cp}^{*} \mathrm{RuCl}\left(\mathrm{PPh}_{3}\right)_{2}\right)$ regioselectively yielding, after stirring overnight the mixture in refluxing 1,4-dioxane, the corresponding 1,5-disubstituted 1,2,3-triazole 19a (Table 2, entry 4). ${ }^{1} \mathrm{H},{ }^{13} \mathrm{C}, \mathrm{TLC}, \mathrm{UHPLC}$, and HMBC unambiguously confirmed the different nature of the two compounds (see Supporting Information) [50].

Once optimal conditions for the regioselective synthesis of 1,4-disubstituted 1,2,3-triazoles were established, we synthesized five azides of different chemical nature including aromatic, heteroaromatic and aliphatic elements $(\mathbf{1 7} \mathbf{b}-\mathbf{f})$. This was achieved by stirring overnight at room temperature the corresponding bromo compounds with an excess (1.5 eq) of sodium azide. The five azides were reacted with alkyne $\mathbf{1 5}$ applying the previously found conditions and products $\mathbf{1 8 b}-\mathbf{f}$ were isolated in good to excellent yields (60-88\%, Table 2, entry 5-9).

As the synthesis of triazoles substituted with short alkyl chains (e.g., methyl, butyl) was unattainable by this route because of safety issues related to the explosive and unstable nature of the required azides, we installed the desired substituents on the triazole scaffold via alkylation. We elected to use a single, small and dangerous azide (i.e., TMSN 3 ) over the use of four different ones. The acetal protected terminal alkyne 16 was carefully reacted with an excess (10.0 eq) of TMSN 3 under previously established CuAAC conditions. The resulting unsubstituted triazole (20, Scheme 3) 
was both deprotected under acidic conditions (18g, Scheme 3) and, to install the desired substituents, alkylated with four different (i.e., methyl, cyclopropylmethyl, butyl, ethoxyethyl) bromides (Scheme 3).

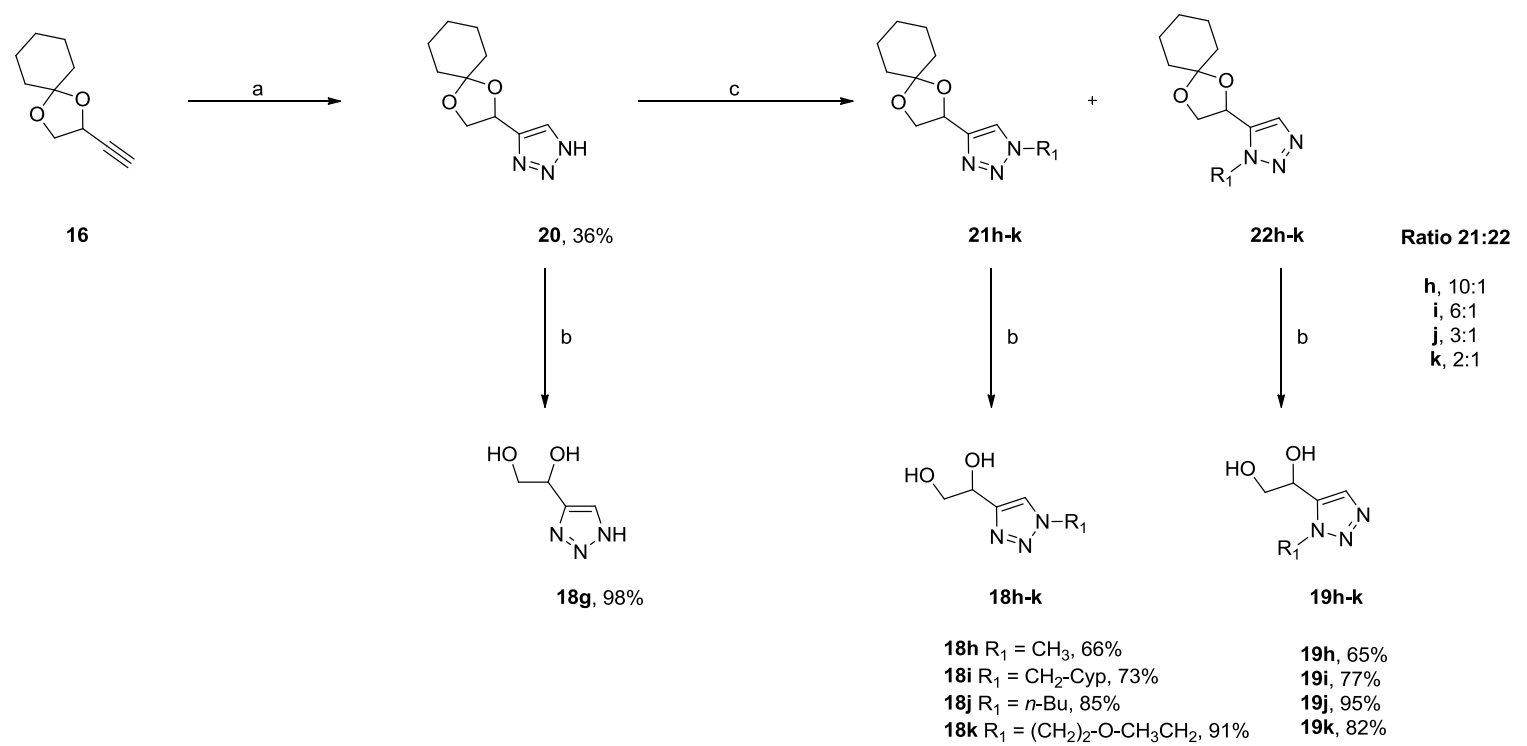

Scheme 3. The synthesis of 1,4-disubstituted 1,2,3-triazoles $\mathbf{1 8 g}$-k and 1,5-disubstituted 1,2,3-triazoles 19h-k. Reagents and conditions: (a) $\mathrm{TMSN}_{3}$ (10.0 eq), $\mathrm{CuSO}_{4} \cdot 5 \mathrm{H}_{2} \mathrm{O}(5 \% \mathrm{~mol}), \mathrm{Na}$ ascorbate (0.5 eq), $t$ - $\mathrm{BuOH} / \mathrm{H}_{2} \mathrm{O}(1: 1)$, $\mathrm{rt}$, overnight; (b) $12 \mathrm{M} \mathrm{HCl}$ (cat.), 1,4-dioxane, $0{ }^{\circ} \mathrm{C}$ to rt, $1-3 \mathrm{~h}$; (c) $\mathrm{R}_{1} \mathrm{Br}(1.5 \mathrm{eq}$ ), $\mathrm{K}_{2} \mathrm{CO}_{3}(2.0 \mathrm{eq}), \mathrm{THF}, 40^{\circ} \mathrm{C}$, overnight; preparative HPLC.

As expected, no regioselectivity was observed and both the 1,4- and the 1,5-disubstituted 1,2,3-triazoles formed. Experimenting with base (i.e, $1.1 \mathrm{eq}, 1.3 \mathrm{eq}$ and $1.5 \mathrm{eq}$ of $\mathrm{K}_{2} \mathrm{CO}_{3}$ ) and/or the alkylbromides (i.e., $0.8 \mathrm{eq}$ and 0.9 eq of $\mathrm{R}_{1} \mathrm{Br}$ ) stoichiometry did not consistently changed the ratio of the two regioisomers (data not shown). For each substituent, the two corresponding regioisomers were isolated by preparative HPLC. The resulting eight products $(\mathbf{2 1} \mathbf{h}-\mathbf{k}$ and $\mathbf{2 2} \mathbf{h}-\mathbf{k}$, Scheme 3) were lastly deprotected with a catalytic amount of concentrated hydrochloric acid. The ratio of the two regioisomers was determined by crude NMR. For all of the four regioisomeric pairs, the 1,4-dibustituted 1,2,3-triazoles formed in excess when compared to the respective 1,5-regioisomers and, as predictable, the ratio decreased as the sterical hindrance of the $R_{1}$ substituent increased (Scheme 3). Concentrated $\mathrm{HCl}$ was preferred over Dowex 50WX8 for the removal of the acetal protecting group due to the shorter reaction time ( $1-3 \mathrm{~h}$ vs. overnight) and shorter workup (no filtration to remove the acidic resin required).

\subsubsection{3,5-Disubstituted Isoxazoles DPD-Derivatives (Series III and IV)}

Compound 15 (Scheme 2) is also the key intermediate for the synthesis of 3,5-disubstituded DPD

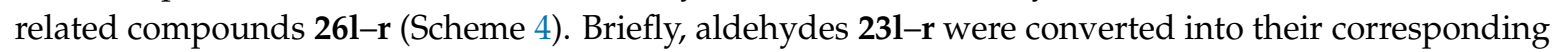
oximes 24l-r using $\mathrm{NH}_{2} \mathrm{OH} \cdot \mathrm{HCl}$. The resulting crude compounds were directly chlorinated by a reaction with $\mathrm{N}$-chlorosuccinimide (NCS). According to Himo et al. [49], the addition of $\mathrm{CuSO}_{4} \cdot 5 \mathrm{H}_{2} \mathrm{O}$, $\mathrm{Na}$ ascorbate, and $\mathrm{KHCO}_{3}$ in $t-\mathrm{BuOH} / \mathrm{H}_{2} \mathrm{O}(1: 1)$ to the isolated chloro-oximes allowed them to form the nitrile oxide which reacted by 1,3-dipolar cycloaddition with 15. After preparative HPLC

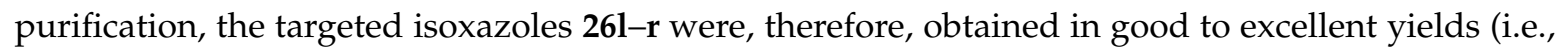
63-89\%, Scheme 4). 


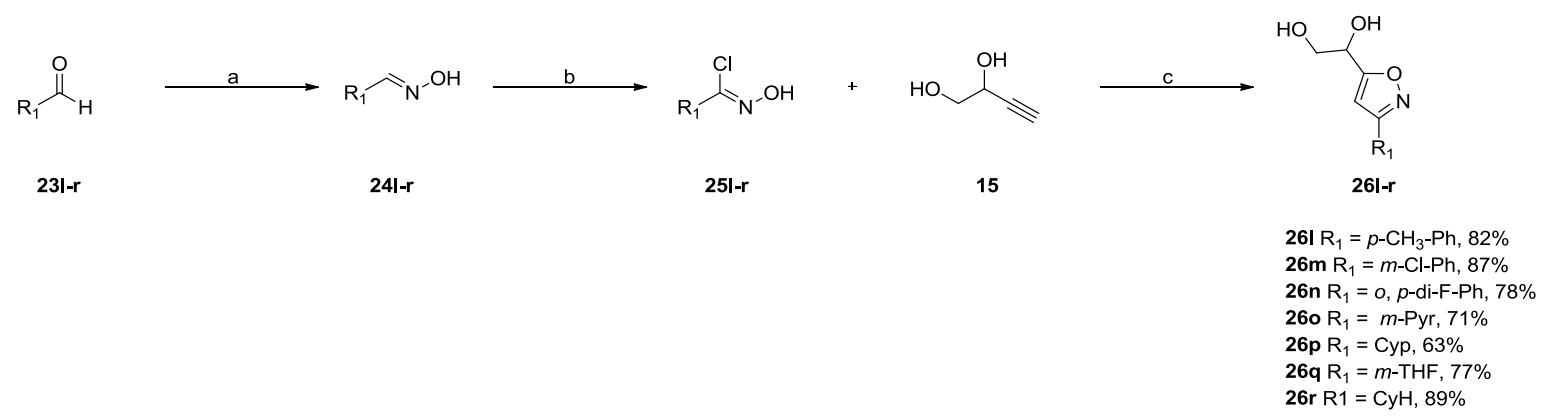

Scheme 4. The synthesis of 3,5-disubstituted isoxazoles 261-r. Reagents and conditions:

(a) $\mathrm{NH}_{2} \mathrm{OH} \cdot \mathrm{HCl}$ (3.0 eq), $\mathrm{Et}_{3} \mathrm{~N}$ (1.5 eq), $\mathrm{H}_{2} \mathrm{O} / \mathrm{EtOH}$ (1:1), rt, 1-3 h; (b) NCS (1.0 eq), DMF, rt, 1-2 h;

(c) 15 (1.0 eq), $\mathrm{CuSO}_{4} \cdot 5 \mathrm{H}_{2} \mathrm{O}(5 \% \mathrm{~mol}), \mathrm{Na}$ ascorbate $(0.5 \mathrm{eq}), \mathrm{KHCO}_{3}, t-\mathrm{BuOH} / \mathrm{H}_{2} \mathrm{O}(1: 1)$, rt, overnight.

The same procedure was attempted to obtain 3,5-disubstituted isoxazoles of DPD-analogs bearing an amide moiety at position 3, but starting from the protected precursor $\mathbf{1 6}$ instead of $\mathbf{1 5}$ due to the cross-reactivity between the 1,3-diol and the reagents necessary in the following steps (e.g., $\mathrm{NaOH}$, DIPEA, Scheme 5). Formation of the nitrile oxide for the cycloaddition was attempted using the dehydration of ethyl nitroacetate with several bases (i.e., DABCO, DMAP, DBU, NMI, Scheme S1, conditions a) and also with a combination of $\mathrm{PhNCO} / \mathrm{Et}_{3} \mathrm{~N}$ (Scheme S1, conditions b), commonly used to activate nitro groups. All of the aforementioned methods resulted in a mixture of unreacted starting materials [51,52].

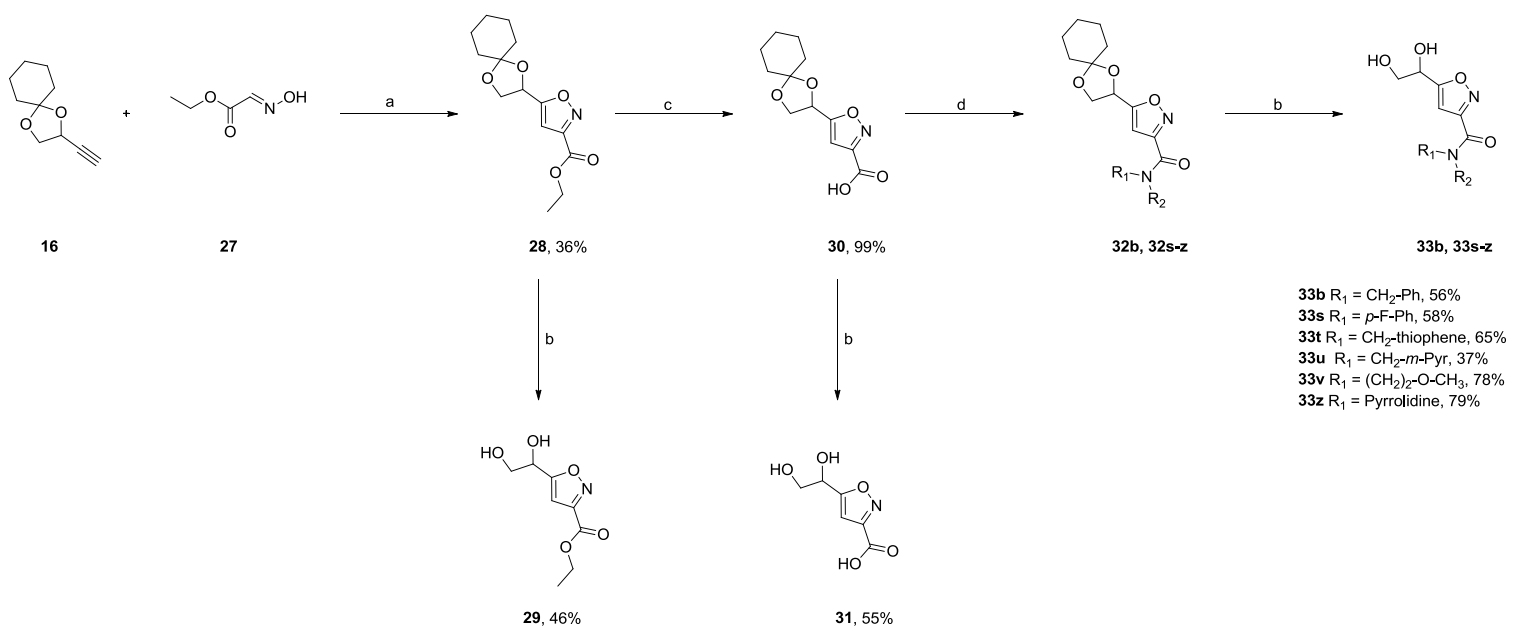

Scheme 5. The synthesis of 3,5-disubstituted isoxazoles (with an amide moiety at position 3) 33b, 33s-z. Reagents and conditions: (a) 27 (2.0 eq), $\mathrm{NaOCl}$ (40.0 eq), THF, rt, 12 h; (b) $12 \mathrm{M} \mathrm{HCl}$ (cat.), 1,4-dioxane, $0{ }^{\circ} \mathrm{C}$ to rt, $1-3 \mathrm{~h}$; (c) NaOH 1M (3.0 eq), THF, rt, overnight; (d) amine (2.0 eq), HOBt (2.0 eq), EDC ${ }^{*} \mathrm{HCl}$ (2.0 eq), $\mathrm{Et}_{3} \mathrm{~N}, \mathrm{DCM}, \mathrm{rt}$, overnight.

The 1,3-dipole species was then changed to the chloro-oxime of ethyl glyoxalate ( $50 \%$ solution in toluene) but the employment of the same conditions as above $\left(\mathrm{CuSO}_{4} \cdot 5 \mathrm{H}_{2} \mathrm{O}(5 \% \mathrm{~mol}), \mathrm{Na}\right.$ ascorbate (0.5 eq), $\mathrm{KHCO}_{3}, t-\mathrm{BuOH} / \mathrm{H}_{2} \mathrm{O}(1: 1)$, Scheme 4) did not yield the desired product while the simple use of an equimolar amount of $\mathrm{Et}_{3} \mathrm{~N}$ gave only traces of 28 (Scheme 5) [49,53].

We then change our strategy and employed the oxime of ethyl glyoxalate 27 together with an excess (40.0 eq) of sodium hypochlorite, both as a chlorinating agent and as a base to form the corresponding nitrile oxide, following the procedure already described by Quan et al. [54]. Compound 28 was successfully obtained, even if with a low yield (16\%). Different reaction times, as well as ratios of dipolarophile $\mathbf{1 6}$ and 1,3-dipole 28, were then tested (Table S2) in order to improve the initially poor yield (i.e., 16\%, Table S2). Increasing the concentration of 1,3-dipole 27 enhanced the formation of 
intermediate 28 up to a maximum of $36 \%$ isolated yield (Table S2) with the complete consumption of the dipolarophile 16 , followed by removal of the excess of 27 by column chromatography.

Once a solution for the key 1,3-dipolar cycloaddition step was found, the rest of the synthetic pathway proceeded smoothly (Scheme 5). Saponification of the ethylic ester was followed by the amidification of the resulting carboxylic acid moiety using HOBt as the coupling agent and employing both primary and secondary amines (aromatic, heteroaromatic, aliphatic). The final acidic removal of the acetal protecting group afforded six 3,5-disubstituted isoxazoles (with an amide moiety at position 3) $\mathbf{3 3 b}, \mathbf{3 3 s - z}$ in moderate to excellent yields (i.e., 37-79\%, Scheme 5). Two more products were isolated after the acidic deprotection of intermediates 28 and 30 (i.e., 29 and 31, respectively, Scheme 5).

\subsection{Biological Evaluation of Synthetized Compounds}

The activity of the synthetized compounds was evaluated with a bioluminescence-based assay against the target enzyme. Our results clearly highlight that racemic DPD prepared using our procedure is efficiently phosphorylated by LsrK (see Supporting Information, Figure S1). In fact, the level of ATP is significantly reduced by the addition of racemic DPD, resulting in a light emission lower than the sample including only LsrK and ATP.

These results confirmed the validity of the approach adopted. Indeed, in this initial phase of the drug discovery process, we prepared racemic DPD and studied a versatile synthesis suitable for readily supporting practical chemical diversification racemic compounds. Only once the most active ones have been identified will both enantiomers be prepared for biological testing. Accordingly, the activity of racemic DPD is essential for demonstrating that our approach has a valid basis. Regarding the DPD-derivatives, unfortunately, they did not show any activity (the data are reported in Supporting Information, Table S3).

\section{Experimental}

\subsection{Chemistry}

Chemicals and solvents were obtained from commercial suppliers and were used without further purification. All dry reactions were performed under a nitrogen atmosphere using commercial dry solvents. Flash column chromatography was performed on a silica column using 230-400 mesh silica gel or the Grace Reveleris X2 flash chromatography system using silica gel packed Macherey Nagel Chromabond Flash BT cartridges ( $60 \AA, 45 \mu \mathrm{m})$ and Grace Reveleris flash Cartridges $(60 \AA, 40 \mu \mathrm{m})$. Thin layer chromatography was performed on Macherey Nagel precoated TLC aluminum sheets with silica gel 60 UV254 (5-17 $\mu \mathrm{m})$. TLC visualization was accomplished by irradiation with a UV lamp $(254 \mathrm{~nm})$ and / or staining with $\mathrm{KMnO}_{4}$ solutions. ${ }^{1} \mathrm{H}-\mathrm{NMR}$ spectra were recorded at room temperature on a Bruker Avance spectrometer operating at $300 \mathrm{MHz}$ (Hamburg, Germany). Chemical shifts are given in ppm $(\delta)$ from tetramethylsilane as an internal standard or residual solvent peak. Significant ${ }^{1}$ H-NMR data are tabulated in the following order: multiplicity (s, singlet; $d$, doublet; $t$, triplet; $q$, quartet; $\mathrm{m}$, multiplet; $\mathrm{dd}$, doublet of doublets; dt, doublet of triplets; $\mathrm{td}$, triplet of doublets; br, broad), coupling constant(s) in hertz, number of protons. Proton decoupled ${ }^{13} \mathrm{C}-\mathrm{NMR}$ data were acquired at $100 \mathrm{MHz} .{ }^{13} \mathrm{C}$ chemical shifts are reported in parts per million $(\delta, \mathrm{ppm})$. All NMR data were collected at room temperature $\left(25^{\circ} \mathrm{C}\right)$. Analytical, preparative HPLC and Electron Spray Ionization (ESI) mass spectra were performed on an Agilent UHPLC (1290 Infinity, Santa Clara, CA, USA) and an Agilent Prep-HPLC (1260 Infinity), both equipped with a Diode Array Detector and a Quadrupole MS using mixture gradients of formic acid/water/acetonitrile as solvents. High-resolution electrospray ionization mass spectra (ESI-FTMS) were recorded on a Thermo LTQ Orbitrap (Thermo Electron, Dreieich, Germany) coupled to an 'Accela' HPLC system supplied with a 'Hypersil GOLD' column (Termo Electron). 


\subsection{Synthesis of DPD and Ph-DPD}

Synthesis of 2 and 7: to a stirred solution of ( $t$-butyldimethylsilyloxy)acetaldehyde (1.0 eq) in dry THF, 1-propynylmagnesium bromide was added (over $15 \mathrm{~min}$; $0.5 \mathrm{M}$ in THF, $1.3 \mathrm{eq}$ ) (or phenylethynylmagnesium bromide $(1.0 \mathrm{M}$ in THF, $1.3 \mathrm{eq})$ at $\left.0{ }^{\circ} \mathrm{C}\right)$. After the addition, the reaction was allowed to reach room temperature and stirred for $3 \mathrm{~h}$. The solvent was removed under reduced pressure, the residue was poured into a cold saturated solution of $\mathrm{NH}_{4} \mathrm{Cl}$ and extracted three times with $\mathrm{Et}_{2} \mathrm{O}$. The organic layer was washed twice with water and once with brine, dried over $\mathrm{MgSO}_{4}$, filtered and concentrated in vacuo to yield 2 as a yellowish oil ( $96 \%$ ) or 7 as a yellow oil ( $98 \%)$.

1-[(t-Butyldimethylsilyl)oxy]pent-3-yn-2-ol (2): yellowish oil, 96\%, $R_{f}=0.20\left(\mathrm{CyH} /\right.$ EtOAc 9:1). ${ }^{1} \mathrm{H}-\mathrm{NMR}$ $\left(300 \mathrm{MHz}, \mathrm{CDCl}_{3}\right) \delta 4.36-4.34(\mathrm{~m}, 1 \mathrm{H}), 3.73(\mathrm{dd}, J=3.6 \mathrm{~Hz}, J=10.0 \mathrm{~Hz}, 1 \mathrm{H}), 3.59(\mathrm{dd}, J=7.7 \mathrm{~Hz}$, $J=10.0 \mathrm{~Hz}, 1 \mathrm{H}), 2.57(\mathrm{~s} \mathrm{br}, 1 \mathrm{H}), 1.83(\mathrm{~d}, J=1.9 \mathrm{~Hz}, 3 \mathrm{H}), 0.91(\mathrm{~s}, 9 \mathrm{H}), 0.08(\mathrm{~d}, J=1.3 \mathrm{~Hz}, 6 \mathrm{H}) \mathrm{ppm}$; ${ }^{13} \mathrm{C}-\mathrm{NMR}\left(100 \mathrm{MHz}, \mathrm{CDCl}_{3}\right) \delta 81.8,79.6,67.3,66.3,25.8,18.3,3.5,-5.4 \mathrm{ppm}[55]$.

1-[(t-Butyldimethylsilyl)oxy]-4-phenylbut-3-yn-2-ol (7): yellow oil, 98\%, $R_{f}=0.72(\mathrm{CyH} /$ EtOAc 9:1). ${ }^{1} \mathrm{H}-\mathrm{NMR}\left(300 \mathrm{MHz}, \mathrm{CDCl}_{3}\right) \delta$ 7.45-7.42 (m, 2H), 7.32-7.29 (m, 3H), 4.65-4.60 (m, 1H), $3.87(\mathrm{dd}$, $J=3.8 \mathrm{~Hz}, J=10.0 \mathrm{~Hz}, 1 \mathrm{H}), 3.75(\mathrm{dd}, J=6.9 \mathrm{~Hz}, J=10.0 \mathrm{~Hz}, 1 \mathrm{H}), 2.71(\mathrm{~d}, J=4.9 \mathrm{~Hz}, 1 \mathrm{H}), 0.93(\mathrm{~s}, 9 \mathrm{H})$, $0.13(\mathrm{~d}, J=3.1 \mathrm{~Hz}, 6 \mathrm{H}) \mathrm{ppm} ;{ }^{13} \mathrm{C}-\mathrm{NMR}\left(100 \mathrm{MHz}, \mathrm{CDCl}_{3}\right) \delta 131.8,128.4,128.2,122.5,87.0,85.3,67.0$, 63.6, 25.9, 18.4, 5.3 ppm [56].

Synthesis of 8 and 9: to a stirred solution of 2 (or 7 ) (1.0 eq) in MeOH, Dowex50WX8 100-200 mesh $(100 \mathrm{mg} / 1 \mathrm{~mL}$ ) was added. The reaction was stirred at room temperature overnight. The mixture was filtered through paper and the solvent was evaporated under reduced pressure to yield $\mathbf{8}$ as an orange oil $(98 \%)$ or 9 as an orange oil $(97 \%)$.

Pent-3-yne-1,2-diol (8): orange oil, 98\%, $R_{f}=0.38\left(\mathrm{CHCl}_{3} / \mathrm{MeOH} 9: 1\right) .{ }^{1} \mathrm{H}-\mathrm{NMR}\left(300 \mathrm{MHz}, \mathrm{CDCl}_{3}\right) \delta$ $4.44-4.39(\mathrm{~m}, 1 \mathrm{H}), 3.70(\mathrm{dd}, J=3.8 \mathrm{~Hz}, J=11.3 \mathrm{~Hz}, 1 \mathrm{H}), 3.62(\mathrm{dd}, J=6.6 \mathrm{~Hz}, J=11.3 \mathrm{~Hz}, 1 \mathrm{H}), 2.41(\mathrm{~s} \mathrm{br}$, $2 \mathrm{H}), 1.85(\mathrm{~d}, J=2.1 \mathrm{~Hz}, 3 \mathrm{H}) \mathrm{ppm} ;{ }^{13} \mathrm{C}-\mathrm{NMR}\left(100 \mathrm{MHz}, \mathrm{CDCl}_{3}\right) \delta 82.8,79.7,66.8,63.4,3.5 \mathrm{ppm}$ [32].

4-Phenylbut-3-yne-1,2-diol (9): orange oil, 97\%, $R_{f}=0.44\left(\mathrm{CHCl}_{3} / \mathrm{MeOH} 9: 1\right) .{ }^{1} \mathrm{H}-\mathrm{NMR}(300 \mathrm{MHz}$, $\left.\mathrm{CDCl}_{3}\right) \delta 7.46-7.42(\mathrm{~m}, 2 \mathrm{H}), 7.36-7.29(\mathrm{~m}, 3 \mathrm{H}), 4.69(\mathrm{dd}, J=3.9 \mathrm{~Hz}, J=6.5 \mathrm{~Hz}, 1 \mathrm{H}), 3.87-3.74(\mathrm{~m}$, 2H), 2.23 (s br, $2 \mathrm{H}) \mathrm{ppm} ;{ }^{13} \mathrm{C}-\mathrm{NMR}\left(100 \mathrm{MHz}, \mathrm{CDCl}_{3}\right) \delta 131.8,128.7,128.3,122.0,86.5,86.3,66.6$, $63.7 \mathrm{ppm}[56]$.

Synthesis of 10 and 11: to 8 (or 9) (1.0 eq) cyclohexanone dimethyl ketal (3.0 eq) and a catalytic amount of $p$-TSA was added. The reaction was stirred at room temperature overnight. The solvent was removed under reduced pressure and the crude was re-dissolved in $\mathrm{Et}_{2} \mathrm{O}$ and washed three times with $\mathrm{NaHCO}_{3}$. The organic layer was dried over $\mathrm{MgSO}_{4}$, filtered and concentrated in vacuo to yield $\mathbf{1 0}$ as a yellow oil (64\%) or $\mathbf{1 1}$ as a yellow oil (72\%).

2-(Prop-1-yn-1-yl)-1,4-dioxaspiro[4.5]decane (10): yellow oil, 64\%, $R_{f}=0.50(\mathrm{CyH} / \mathrm{EtOAc} 9: 1) .{ }^{1} \mathrm{H}-\mathrm{NMR}$ $\left(300 \mathrm{MHz}, \mathrm{CDCl}_{3}\right) \delta 4.70-4.64(\mathrm{~m}, 1 \mathrm{H}), 4.11(\mathrm{dd}, J=6.2 \mathrm{~Hz}, J=7.9 \mathrm{~Hz}, 1 \mathrm{H}), 3.81(\mathrm{t}, J=7.5 \mathrm{~Hz}, 1 \mathrm{H}), 1.85$ $(\mathrm{d}, J=2.1 \mathrm{~Hz}, 3 \mathrm{H}), 1.74-1.70(\mathrm{~m}, 2 \mathrm{H}), 1.65-1.57(\mathrm{~m}, 6 \mathrm{H}), 1.43-1.38(\mathrm{~m}, 2 \mathrm{H}) \mathrm{ppm} ;{ }^{13} \mathrm{C}-\mathrm{NMR}(100 \mathrm{MHz}$, $\left.\mathrm{CDCl}_{3}\right) \delta 110.5,85.8,82.3,69.7,65.5,35.8,25.1,23.9,3.7 \mathrm{ppm} \mathrm{[32].}$

2-(2-Phenylethynyl)-1,4-dioxaspiro[4.5]decane (11): yellow oil, 72\%, $R_{f}=0.60$ (CyH/EtOAc 9:1). ${ }^{1} \mathrm{H}-\mathrm{NMR}$ $\left(300 \mathrm{MHz}, \mathrm{CDCl}_{3}\right) \delta 7.46-7.42(\mathrm{~m}, 2 \mathrm{H}), 7.33-7.28(\mathrm{~m}, 3 \mathrm{H}), 4.95(\mathrm{t}, J=6.4 \mathrm{~Hz}, 1 \mathrm{H}), 4.23(\mathrm{dd}, J=6.3 \mathrm{~Hz}$, $J=7.9 \mathrm{~Hz}, 1 \mathrm{H}), 4.01(\mathrm{dd}, J=6.5 \mathrm{~Hz}, J=7.9 \mathrm{~Hz}, 1 \mathrm{H}), 1.81-1.77(\mathrm{~m}, 2 \mathrm{H}), 1.68-1.56(\mathrm{~m}, 6 \mathrm{H}), 1.44-1.41(\mathrm{~m}$, 2H), ppm; ${ }^{13} \mathrm{C}-\mathrm{NMR}\left(100 \mathrm{MHz}, \mathrm{CDCl}_{3}\right) \delta 131.8,128.5,128.2,122.4,111.0,86.6,85.6,69.7,65.7,35.5,25.1$, $23.9 \mathrm{ppm}$. 
Synthesis of 12 and 13: to a stirred solution of 10 (or 11) (1.0 eq) in a 1:1:1 mixture of $\mathrm{CHCl}_{3} / \mathrm{ACN} / \mathrm{H}_{2} \mathrm{O}, \mathrm{NaIO}_{4}(4.4 \mathrm{eq})$ and $\mathrm{RuO}_{2} \cdot \mathrm{H}_{2} \mathrm{O}(2.5 \% \mathrm{~mol})$ were added. The mixture was vigorously stirred at room temperature overnight. The solvent was evaporated under reduced pressure and the crude was re-dissolved in $\mathrm{CHCl}_{3}$ and filtered through a silica pad. The eluate was washed three times with water, dried over $\mathrm{MgSO}_{4}$, filtered and concentrated in vacuo to yield 12 as a yellow oil (54\%) or 13 as yellow oil ( $47 \%)$.

1-\{1,4-Dioxaspiro[4.5]decan-2-yl\}propane-1,2-dione (12): yellow oil, 54\%, $R_{f}=0.42(\mathrm{CyH} /$ EtOAc 3:1). ${ }^{1} \mathrm{H}-\mathrm{NMR}\left(300 \mathrm{MHz}, \mathrm{CDCl}_{3}\right) \delta 5.14(\mathrm{dd}, J=5.3 \mathrm{~Hz}, J=7.9 \mathrm{~Hz}, 1 \mathrm{H}), 4.35(\mathrm{dd}, J=8.0 \mathrm{~Hz}, J=8.9 \mathrm{~Hz}, 1 \mathrm{H})$, $3.99(\mathrm{dd}, J=5.3 \mathrm{~Hz}, J=8.9 \mathrm{~Hz}, 1 \mathrm{H}), 2.39(\mathrm{~s}, 3 \mathrm{H}), 1.66-1.57(\mathrm{~m}, 8 \mathrm{H}), 1.45-1.42(\mathrm{~m}, 2 \mathrm{H}) \mathrm{ppm} ;{ }^{13} \mathrm{C}-\mathrm{NMR}$ $\left(100 \mathrm{MHz}, \mathrm{CDCl}_{3}\right) \delta 197.5,190.0,109.2,75.9,66.9,36.4,35.6,25.9,24.8,24.0 \mathrm{ppm}[28]$.

1-\{1,4-Dioxaspiro[4.5]decan-2-yl\}-2-phenylethane-1,2-dione (13): yellow oil, 47\%, $R_{f}=0.46(\mathrm{CyH} / \mathrm{EtOAc}$ 9:1). ${ }^{1} \mathrm{H}-\mathrm{NMR}\left(300 \mathrm{MHz}, \mathrm{CDCl}_{3}\right), \delta 7.98(\mathrm{~d}, J=7.1 \mathrm{~Hz}, 2 \mathrm{H}), 7.66(\mathrm{~d}, J=7.4 \mathrm{~Hz}, 1 \mathrm{H}), 7.51(\mathrm{t}, J=7.7 \mathrm{~Hz}$, $2 \mathrm{H}), 5.12(\mathrm{t}, J=6.2 \mathrm{~Hz}, 1 \mathrm{H}), 4.34(\mathrm{~d}, J=6.4 \mathrm{~Hz}, 2 \mathrm{H}), 1.65-1.49(\mathrm{~m}, 8 \mathrm{H}), 1.39-1.32(\mathrm{~m}, 2 \mathrm{H}) \mathrm{ppm} ;{ }^{13} \mathrm{C}-\mathrm{NMR}$ $\left(100 \mathrm{MHz}, \mathrm{CDCl}_{3}\right) \delta$ 200.5, 193.0, 134.9, 132.2, 129.9, 128.9, 112.2, 77.9, 65.9, 35.4, 34.6, 24.9, 23.8, $23.0 \mathrm{ppm}$.

Synthesis of DPD and Ph-DPD: to a stirred solution of 12 (or 13) (10 mM) in $\mathrm{D}_{2} \mathrm{O}$, Dowex 50WX8 resin was added $(100 \mathrm{mg} / 1 \mathrm{~mL})$. The mixture was stirred at room temperature overnight. The mixture was filtered to remove the resin and extracted with $\mathrm{CDCl}_{3}$ to remove the released cyclohexanone.

4,5-Dihydroxy-2,3-pentanedione (DPD): ${ }^{1} \mathrm{H}-\mathrm{NMR}\left(300 \mathrm{MHz}, \mathrm{D}_{2} \mathrm{O}\right) \delta 4.41-4.37(\mathrm{~m}, 1 \mathrm{H}), 4.21-4.14(\mathrm{~m}, 2 \mathrm{H})$, $4.07(\mathrm{dd}, J=3.2 \mathrm{~Hz}, J=6.0 \mathrm{~Hz}, 1 \mathrm{H}), 3.99(\mathrm{dd}, J=3.8 \mathrm{~Hz}, J=7.4 \mathrm{~Hz}, 1 \mathrm{H}), 3.86-3.78(\mathrm{~m}, 2 \mathrm{H}), 3.69-3.65$ $(\mathrm{m}, 1 \mathrm{H}), 3.59(\mathrm{dd}, J=5.6 \mathrm{~Hz}, J=9.4 \mathrm{~Hz}, 1 \mathrm{H}), 2.39(\mathrm{~s}, 3 \mathrm{H}), 1.46(\mathrm{~s}, 3 \mathrm{H}), 1.43(\mathrm{~s}, 3 \mathrm{H}) \mathrm{ppm}$ [34]. The NMR shows that some cyclohexanone is left as two multiplets at 1.88-1.86 and 1.75-1.74 ppm.

3,4-Dihydroxy-1-phenylbutane-1,2-dione (Ph-DPD): ${ }^{1} \mathrm{H}-\mathrm{NMR}\left(300 \mathrm{MHz}, \mathrm{D}_{2} \mathrm{O}\right) \delta 8.25-8.15(\mathrm{~m}, 2 \mathrm{H})$, 8.07-7.92 (m, 2H), 7.73-7.68 (m, 1H), 7.62-7.59 (m, 5H), 7.48-7.46 (m, 5H), 4.49-4.42 (m, 1H), 4.40-4.36 $(\mathrm{m}, 1 \mathrm{H}), 4.13(\mathrm{dd}, J=2.7 \mathrm{~Hz}, J=5.6 \mathrm{~Hz}, 1 \mathrm{H}), 4.09(\mathrm{~d}, J=2.8 \mathrm{~Hz}, 1 \mathrm{H}), 4.06(\mathrm{~d}, J=2.6 \mathrm{~Hz}, 1 \mathrm{H}), 3.88(\mathrm{~d}$, $J=4.0 \mathrm{~Hz}, 1 \mathrm{H}), 3.85-3.79(\mathrm{~m}, 1 \mathrm{H}), 3.73-3.66(\mathrm{~m}, 1 \mathrm{H}) \mathrm{ppm}[30]$.

Synthesis of quinoxaline-DPD and quinoxaline-Ph-DPD: to a stirred solution of DPD (or Ph-DPD) in $\mathrm{D}_{2} \mathrm{O}$, o-phenylendiamine (2.0 eq) was added. The reaction was stirred at room temperature overnight. The solvent was evaporated under reduced pressure, the crude was re-dissolved in ACN (1 mL), filtered and purified by preparative HPLC.

1-(3-Methylquinoxalin-2-yl)ethane-1,2-diol (Quinoxaline-DPD): orange solid, $R_{f}=0.52\left(\mathrm{CHCl}_{3} / \mathrm{MeOH}\right.$ 9:1). ${ }^{1} \mathrm{H}-\mathrm{NMR}(700 \mathrm{MHz}, \mathrm{MeOD}) \delta 8.09-8.07(\mathrm{~m}, 1 \mathrm{H}), 7.98-7.97(\mathrm{~m}, 1 \mathrm{H}), 7.76(\mathrm{pd}, J=7.0 \mathrm{~Hz}, J=1.6 \mathrm{~Hz}$, $2 \mathrm{H}), 5.15-5.13(\mathrm{~m}, 1 \mathrm{H}), 4.02(\mathrm{dd}, J=11.4 \mathrm{~Hz}, J=5.4 \mathrm{~Hz}, 1 \mathrm{H}), 3.96(\mathrm{dd}, J=11.4 \mathrm{~Hz}, J=6.3 \mathrm{~Hz}, 1 \mathrm{H})$, $2.84(\mathrm{~s}, 3 \mathrm{H}) \mathrm{ppm} ;{ }^{13} \mathrm{C}-\mathrm{NMR}(176 \mathrm{MHz}, \mathrm{MeOD}) \delta 156.6,154.7,142.3,141.8,131.2,130.5,129.9,128.8$, 72.9, 66.3, 22.3 ppm; HRMS (ESI-MS) calcd. for $\mathrm{C}_{11} \mathrm{H}_{12} \mathrm{~N}_{2} \mathrm{O}_{2}[\mathrm{M}+\mathrm{H}]^{+}=205.0899$. Found: 205.0972. The NMR was consistent with previously reported data [18]. The NMR was measured with a Bruker DRX700 (700 MHz).

1-(3-Phenylquinoxalin-2-yl)ethane-1,2-diol (Quinoxaline-Ph-DPD): orange solid, $R_{f}=0.48$ $\left(\mathrm{CHCl}_{3} / \mathrm{MeOH} 9: 1\right) .{ }^{1} \mathrm{H}-\mathrm{NMR}\left(700 \mathrm{MHz}, \mathrm{CDCl}_{3}\right) \delta 8.18(\mathrm{dd}, J=6.4 \mathrm{~Hz}, J=3.3 \mathrm{~Hz}, 1 \mathrm{H})$, $8.13(\mathrm{dd}, J=6.1 \mathrm{~Hz}, J=3.6 \mathrm{~Hz}, 1 \mathrm{H}), 7.82(\mathrm{dd}, J=6.4 \mathrm{~Hz}, J=3.4 \mathrm{~Hz}, 2 \mathrm{H}), 7.68(\mathrm{dd}, J=7.8 \mathrm{~Hz}, J=1.3$ $\mathrm{Hz}, 2 \mathrm{H}), 7.57-7.53(\mathrm{~m}, 3 \mathrm{H}), 5.30(\mathrm{dd}, J=4.9 \mathrm{~Hz}, J=3.6 \mathrm{~Hz}, 1 \mathrm{H}), 3.74(\mathrm{dd}, J=11.7 \mathrm{~Hz}, J=3.4 \mathrm{~Hz}, 1 \mathrm{H})$, $3.54(\mathrm{dd}, J=11.7 \mathrm{~Hz}, 5.1 \mathrm{~Hz}, 1 \mathrm{H}) \mathrm{ppm} ;{ }^{13} \mathrm{C}-\mathrm{NMR}\left(176 \mathrm{MHz}, \mathrm{CDCl}_{3}\right) \delta 153.7,152.5,141.8,139.6,137.6$, $130.5,130.4,129.6,129.4,129.0,128.8,128.4,70.6,65.7$ ppm. HRMS (ESI-MS) calcd. for C16H14N2O2 
$[\mathrm{M}+\mathrm{H}]^{+}=267.1055$. Found: 267.1129 . The NMR was consistent with previously reported data [57]. The NMR was measured with a Bruker DRX700 (700 MHz).

\subsection{General Procedures for the Synthesis of 1,4- and 1,5-Disubstituted Triazoles DPD-Derivatives (Series I} and II)

Synthesis of 1-[(t-butyldimethylsilyl)oxy]but-3-yn-2-ol (14): to a stirred solution of ( $t$-butyldimethylsilyloxy)acetaldehyde (1.0 eq) in dry THF, ethynylmagnesium bromide ( $0.50 \mathrm{M}$ in THF, 1.3 eq) was added over 15 minutes at $0{ }^{\circ} \mathrm{C}$. After the addition, the reaction was allowed to reach room temperature and stirred for 3 hours. The solvent was removed under reduced pressure, the residue was poured into a cold saturated solution of $\mathrm{NH}_{4} \mathrm{Cl}$ and extracted three times with $\mathrm{Et}_{2} \mathrm{O}$. The organic layer was washed twice with water and once with brine, dried over $\mathrm{MgSO}_{4}$, filtered and concentrated in vacuo to yield 14 as a yellow oil, 99\%, $R_{f}=0.55(\mathrm{CyH} / \mathrm{EtOAc} 3: 1) .{ }^{1} \mathrm{H}-\mathrm{NMR}\left(300 \mathrm{MHz}, \mathrm{CDCl}_{3}\right) \delta$ $4.40-4.37(\mathrm{~m}, 1 \mathrm{H}), 3.79(\mathrm{dd}, J=3.8 \mathrm{~Hz}, J=10.1 \mathrm{~Hz}, 1 \mathrm{H}), 3.66(\mathrm{dd}, J=6.8 \mathrm{~Hz}, J=10.0 \mathrm{~Hz}, 1 \mathrm{H}), 2.62(\mathrm{~d}$, $J=5.1 \mathrm{~Hz}, 1 \mathrm{H}), 2.42(\mathrm{~d}, J=2.2 \mathrm{~Hz}, 1 \mathrm{H}), 0.91(\mathrm{~s}, 9 \mathrm{H}), 0.10(\mathrm{~d}, J=1.5 \mathrm{~Hz}, 6 \mathrm{H}) \mathrm{ppm} ;{ }^{13} \mathrm{C}-\mathrm{NMR}(100 \mathrm{MHz}$, $\left.\mathrm{CDCl}_{3}\right) \delta 81.9,73.4,66.8,62.9,25.8,18.3,-5.4$ ppm [58].

Synthesis of but-3-yne-1,2-diol (15): to a stirred solution of 14 in $\mathrm{MeOH}$, a Dowex50WX8 100-200 mesh (100 mg/1 mL) was added. The reaction was stirred at room temperature overnight. The mixture was filtered through paper and the solvent was evaporated under reduced pressure to yield 15 as an orange oil, $99 \%, R_{f}=0.50\left(\mathrm{CHCl}_{3} / \mathrm{MeOH} 9: 1\right) .{ }^{1} \mathrm{H}-\mathrm{NMR}\left(300 \mathrm{MHz}, \mathrm{CDCl}_{3}\right) \delta 4.49-4.45$ $(\mathrm{m}, 1 \mathrm{H}), 3.80-3.68(\mathrm{~m}, 1 \mathrm{H}), 2.51(\mathrm{~d}, J=2.2 \mathrm{~Hz}, 1 \mathrm{H}), 2.31(\mathrm{~s}, 2 \mathrm{H}) \mathrm{ppm} ;{ }^{13} \mathrm{C}-\mathrm{NMR}\left(100 \mathrm{MHz}, \mathrm{CDCl}_{3}\right) \delta$ 81.5, 74.3, 66.3, 63.0 ppm [59].

Synthesis of 2-ethynyl-1,4-dioxaspiro[4.5]decane (16): to 15 (1.0 eq) cyclohexanone dimethyl ketal (10.0 eq) and a catalytic amount of $p$-TSA were added. The reaction was stirred at room temperature overnight. The solvent was removed under reduced pressure and the crude was re-dissolved in $\mathrm{Et}_{2} \mathrm{O}$ and washed three times with $\mathrm{NaHCO}_{3}$. The organic layer was dried over $\mathrm{MgSO}_{4}$, filtered and concentrated in vacuo to yield 16 as a yellow oil, $57 \%, R_{f}=0.42(\mathrm{CyH} / \mathrm{EtOAc}$ 9:1). ${ }^{1} \mathrm{H}-\mathrm{NMR}\left(300 \mathrm{MHz}, \mathrm{CDCl}_{3}\right) \delta 4.71(\mathrm{dt}, J=2.0 \mathrm{~Hz}, J=6.3 \mathrm{~Hz}, 1 \mathrm{H}), 4.16(\mathrm{dd}, J=6.4 \mathrm{~Hz}, J=8.0 \mathrm{~Hz}$, $1 \mathrm{H}), 3.94(\mathrm{dd}, J=6.3 \mathrm{~Hz}, J=8.0 \mathrm{~Hz}, 1 \mathrm{H}), 2.48(\mathrm{~d}, J=2.0 \mathrm{~Hz}, 1 \mathrm{H}), 1.77-1.72(\mathrm{~m}, 2 \mathrm{H}), 1.65-1.59(\mathrm{~m}$, 6H), 1.42-1.39 (m, 2H) ppm; ${ }^{13} \mathrm{C}-\mathrm{NMR}\left(100 \mathrm{MHz}, \mathrm{CDCl}_{3}\right) \delta 111.2,81.6,73.7,69.5,64.9,35.6,25.0$, $23.8 \mathrm{ppm}[30]$.

General procedure for the synthesis of $\mathbf{1 7 a}-\mathrm{f}$ : to a stirred suspension of $\mathrm{NaN}_{3}(1.5 \mathrm{eq})$ in DMSO ( $5 \mathrm{~mL})$, the corresponding bromo compound (1.0 eq) was added. The reaction was stirred at room temperature overnight. The mixture was diluted with diethyl ether and extracted five times with water and once with brine, dried over $\mathrm{MgSO}_{4}$, filtered and concentrated in vacuo to yield the desired azide as a colorless/yellowish oil.

General procedure for the synthesis of 18a-f: to a stirred solution of $\mathbf{1 5}(1.0 \mathrm{eq})$ in a 1:1 mixture of $\mathrm{H}_{2} \mathrm{O} / t-\mathrm{BuOH}$, the corresponding azide $(1.0 \mathrm{eq})$, sodium ascorbate $(0.5 \mathrm{eq})$ and $\mathrm{CuSO}_{4} \cdot 5 \mathrm{H}_{2} \mathrm{O}$ $(5 \% \mathrm{~mol})$ were added. The reaction was stirred at room temperature overnight. The solvent was evaporated under reduced pressure, the crude was redissolved in ACN $(1 \mathrm{~mL})$, filtered and purified by preparative HPLC [49].

1-[1-(2-Phenylethyl)-1H-1,2,3-triazol-4-yl]ethane-1,2-diol (18a): orange oil, 89\%, $R_{f}=0.24\left(\mathrm{CHCl}_{3} / \mathrm{MeOH}\right.$ 9:1), UHPLC-ESI-MS: $R_{t}=1.80, m / z=234.2[\mathrm{M}+\mathrm{H}]^{+} .{ }^{1} \mathrm{H}-\mathrm{NMR}\left(300 \mathrm{MHz}, \mathrm{CD}_{3} \mathrm{CN}\right) \delta 7.56(\mathrm{~s}, 1 \mathrm{H})$, $7.31-7.20(\mathrm{~m}, 3 \mathrm{H}), 7.15(\mathrm{~d}, J=6.7 \mathrm{~Hz}, 2 \mathrm{H}), 4.75(\mathrm{dd}, J=4.3 \mathrm{~Hz}, J=6.7 \mathrm{~Hz}, 1 \mathrm{H}), 4.57(\mathrm{t}, J=7.3 \mathrm{~Hz}, 2 \mathrm{H})$, $3.72(\mathrm{dd}, J=4.2 \mathrm{~Hz}, J=11.2 \mathrm{~Hz}, 1 \mathrm{H}), 3.60(\mathrm{dd}, J=6.9 \mathrm{~Hz}, J=11.2 \mathrm{~Hz}, 1 \mathrm{H}), 3.17(\mathrm{t}, J=7.2 \mathrm{~Hz}, 2 \mathrm{H}), 2.23$ (s br, 1H) ppm; ${ }^{13} \mathrm{C}-\mathrm{NMR}\left(100 \mathrm{MHz}, \mathrm{CD}_{3} \mathrm{CN}\right) \delta$ 149.4, 138.8, 129.7, 129.4, 127.6, 122.8, 68.5, 66.8, 51.9, $36.9 \mathrm{ppm}$.

1-(1-Benzyl-1H-1,2,3-triazol-4-yl)ethane-1,2-diol (18b): yellowish oil, 60\%, $R_{f}=0.24\left(\mathrm{CHCl}_{3} / \mathrm{MeOH} 9: 1\right)$, UHPLC-ESI-MS: $R_{t}=1.70, m / z=220.2[\mathrm{M}+\mathrm{H}]^{+} .{ }^{1} \mathrm{H}-\mathrm{NMR}\left(300 \mathrm{MHz}, \mathrm{CD}_{3} \mathrm{CN}\right) \delta 7.72(\mathrm{~s}, 1 \mathrm{H}), 7.38-7.29$ 
$(\mathrm{m}, 5 \mathrm{H}), 5.51(\mathrm{~s}, 2 \mathrm{H}), 4.79(\mathrm{dd}, J=4.4 \mathrm{~Hz}, J=6.3 \mathrm{~Hz}, 1 \mathrm{H}), 3.75(\mathrm{dd}, J=4.2 \mathrm{~Hz}, J=11.2 \mathrm{~Hz}, 1 \mathrm{H}), 3.64(\mathrm{dd}$, $J=6.7 \mathrm{~Hz}, J=11.2 \mathrm{~Hz}, 1 \mathrm{H}) \mathrm{ppm} ;{ }^{13} \mathrm{C}-\mathrm{NMR}\left(100 \mathrm{MHz}, \mathrm{CD}_{3} \mathrm{CN}\right) \delta 150.1,136.9,129.8,129.3,128.9,123.0$, $68.5,66.7,54.4 \mathrm{ppm}$.

1-\{1-[.2-(2-Fluorophenyl)ethyl]-1H-1,2,3-triazol-4-yl\}ethane-1,2-diol (18c): colorless oil, $62 \%, R_{f}=0.49$ $\left(\mathrm{CHCl}_{3} / \mathrm{MeOH} 9: 1\right)$, UHPLC-ESI-MS: $R_{t}=1.82, \mathrm{~m} / z=252.2[\mathrm{M}+\mathrm{H}]^{+} .{ }^{1} \mathrm{H}-\mathrm{NMR}\left(300 \mathrm{MHz}, \mathrm{CD}_{3} \mathrm{CN}\right) \delta$ $7.58(\mathrm{~s}, 1 \mathrm{H}), 7.30-7.23(\mathrm{~m}, 1 \mathrm{H}), 7.14-7.04(\mathrm{~m}, 3 \mathrm{H}), 4.75(\mathrm{dd}, J=4.3 \mathrm{~Hz}, J=6.8 \mathrm{~Hz}, 1 \mathrm{H}), 4.58(\mathrm{t}, J=7.1 \mathrm{~Hz}$, $2 \mathrm{H}), 3.71(\mathrm{dd}, J=4.2 \mathrm{~Hz}, J=11.2 \mathrm{~Hz}, 1 \mathrm{H}), 3.59(\mathrm{dd}, J=6.9 \mathrm{~Hz}, J=11.2 \mathrm{~Hz}, 1 \mathrm{H}), 3.21(\mathrm{t}, J=7.1 \mathrm{~Hz}, 2 \mathrm{H})$, 2.23 (s br, 1H) ppm; ${ }^{13} \mathrm{C}-\mathrm{NMR}\left(100 \mathrm{MHz}, \mathrm{CD}_{3} \mathrm{CN}\right) \delta 162.8(\mathrm{~d}, J=243.8 \mathrm{~Hz}), 150.2,132.9(\mathrm{~d}, J=4.6 \mathrm{~Hz})$, $130.6(\mathrm{~d}, J=8.2 \mathrm{~Hz}), 126.2,126.0(\mathrm{~d}, J=3.5 \mathrm{~Hz}), 123.6,116.8(\mathrm{~d}, J=22.0 \mathrm{~Hz}), 69.2,67.5,51.2,31.3(\mathrm{~d}$, $J=2.4 \mathrm{~Hz}) \mathrm{ppm}$.

1-\{1-[2-(Pyridin-2-yl)ethyl]-1H-1,2,3-triazol-4-yl\}ethane-1,2-diol (18d): yellow oil, 88\%, $R_{f}=0.28$ $\left(\mathrm{CHCl}_{3} / \mathrm{MeOH} 9: 1\right)$, UHPLC-ESI-MS: $R_{t}=0.38, m / z=232.2[\mathrm{M}+\mathrm{H}]^{+} .{ }^{1} \mathrm{H}-\mathrm{NMR}\left(300 \mathrm{MHz}, \mathrm{CD}_{3} \mathrm{CN}\right) \delta$ $8.51(\mathrm{~s}, 1 \mathrm{H}), 7.66-7.59(\mathrm{~m}, 2 \mathrm{H}), 7.21-7.12(\mathrm{~m}, 2 \mathrm{H}), 4.75(\mathrm{t}, J=7.1 \mathrm{~Hz}, 3 \mathrm{H}), 3.71(\mathrm{dd}, J=4.1 \mathrm{~Hz}, J=11.2 \mathrm{~Hz}$, $1 \mathrm{H}), 3.59(\mathrm{dd}, J=6.8 \mathrm{~Hz}, J=11.1 \mathrm{~Hz}, 1 \mathrm{H}), 3.33(\mathrm{t}, J=7.1 \mathrm{~Hz}, 2 \mathrm{H}) \mathrm{ppm} ;{ }^{13} \mathrm{C}-\mathrm{NMR}\left(100 \mathrm{MHz}, \mathrm{CD}_{3} \mathrm{CN}\right) \delta$ $158.5,150.3,143.3,137.5,124.4,123.2,122.8,68.5,66.8,50.0,38.8$ ppm.

6-[4-(1,2-Dihydroxyethyl)-1H-1,2,3-triazol-1-yl]hexanenitrile (18e): orange oil, $72 \%, \quad R_{f}=0.54$ $\left(\mathrm{CHCl}_{3} / \mathrm{MeOH} 9: 1\right)$, UHPLC-ESI-MS: $R_{t}=1.39, \mathrm{~m} / z=225.2[\mathrm{M}+\mathrm{H}]^{+} .{ }^{1} \mathrm{H}-\mathrm{NMR}\left(300 \mathrm{MHz}, \mathrm{CD}_{3} \mathrm{CN}\right) \delta$ $7.68(\mathrm{~s}, 1 \mathrm{H}), 4.78(\mathrm{~s}, 1 \mathrm{H}), 4.34(\mathrm{dt}, J=1.9 \mathrm{~Hz}, J=7.1 \mathrm{~Hz}, 2 \mathrm{H}), 3.76-3.73(\mathrm{~m}, 1 \mathrm{H}), 3.66-3.57(\mathrm{~m}, 1 \mathrm{H}), 3.08(\mathrm{~s}$ br, $1 \mathrm{H}), 2.37(\mathrm{dt}, J=1.9 \mathrm{~Hz}, J=7.1 \mathrm{~Hz}, 2 \mathrm{H}), 1.88-1.83(\mathrm{~m}, 2 \mathrm{H}), 1.68-1.58(\mathrm{~m}, 2 \mathrm{H}), 1.44-1.34(\mathrm{~m}, 2 \mathrm{H}) \mathrm{ppm}$; ${ }^{13} \mathrm{C}-\mathrm{NMR}\left(100 \mathrm{MHz}, \mathrm{CD}_{3} \mathrm{CN}\right) \delta 148.4,121.5,119.8,67.3,65.6,49.2,28.8,24.9,24.2,16.0 \mathrm{ppm}$.

1-[1-(2-Cyclohexylethyl)-1H-1,2,3-triazol-4-yl]ethane-1,2-diol (18f): orange oil, 73\%, $R_{f}=0.43$ $\left(\mathrm{CHCl}_{3} / \mathrm{MeOH}\right.$ 9:1), UHPLC-ESI-MS: $R_{t}=2.20, m / z=240.2[\mathrm{M}+\mathrm{H}]^{+} .{ }^{1} \mathrm{H}-\mathrm{NMR}\left(300 \mathrm{MHz}, \mathrm{CD}_{3} \mathrm{CN}\right) \delta$ $7.69(\mathrm{~s}, 1 \mathrm{H}), 4.78(\mathrm{t}, J=5.3 \mathrm{~Hz}, 1 \mathrm{H}), 4.35(\mathrm{t}, J=7.5 \mathrm{~Hz}, 2 \mathrm{H}), 3.74(\mathrm{~s}, 1 \mathrm{H}), 3.67-3.62(\mathrm{~m}, 1 \mathrm{H}), 2.21(\mathrm{~s} \mathrm{br}$, $1 \mathrm{H}), 1.78-1.63(\mathrm{~m}, 7 \mathrm{H}), 1.24-1.17(\mathrm{~m}, 4 \mathrm{H}), 1.0-0.94(\mathrm{~m}, 2 \mathrm{H}) \mathrm{ppm} ;{ }^{13} \mathrm{C}-\mathrm{NMR}\left(100 \mathrm{MHz}, \mathrm{CD}_{3} \mathrm{CN}\right) \delta 150.4$, $123.5,69.2,67.5,49.4,39.0,36.4,34.2,27.8,27.5 \mathrm{ppm}$.

Synthesis of 1-[1-(2-phenylethyl)-1H-1,2,3-triazol-5-yl]ethane-1,2-diol (19a): to a stirred solution of 15 (1.0 eq) in 1,4-dioxane, (2-azidoethyl)benzene (17a) $\left(1.0\right.$ eq) and $\mathrm{Cp} * \mathrm{RuCl}\left(\mathrm{PPh}_{3}\right)_{2}(2 \%$ mol) were added. The reaction was stirred at reflux overnight. The solvent was evaporated under reduced pressure, the crude was re-dissolved in ACN $(1 \mathrm{~mL})$, filtered and purified by preparative HPLC to yield 19a as a yellow solid, $87 \%, R_{f}=0.17\left(\mathrm{CHCl}_{3} / \mathrm{MeOH} 9: 1\right)$, UHPLC-ESI-MS: $R_{t}=1.75$, $m / z=234.2[\mathrm{M}+\mathrm{H}]{ }^{+} .{ }^{1} \mathrm{H}-\mathrm{NMR}\left(300 \mathrm{MHz}, \mathrm{CD}_{3} \mathrm{CN}\right) \delta 7.51(\mathrm{~s}, 1 \mathrm{H}), 7.28(\mathrm{t}, J=7.3 \mathrm{~Hz}, 2 \mathrm{H}), 7.23(\mathrm{t}$, $J=7.3 \mathrm{~Hz}, 1 \mathrm{H}), 7.15(\mathrm{~d}, J=7.1 \mathrm{~Hz}, 2 \mathrm{H}), 4.62(\mathrm{~d}, J=6.3 \mathrm{~Hz}, 1 \mathrm{H}), 4.61-4.58(\mathrm{~m}, 2 \mathrm{H}), 3.70(\mathrm{~s} \mathrm{br}, 1 \mathrm{H})$, $3.62(\mathrm{dd}, J=6.6 \mathrm{~Hz}, J=11.3 \mathrm{~Hz}, 1 \mathrm{H}), 3.56(\mathrm{dd}, J=4.9 \mathrm{~Hz}, J=11.3 \mathrm{~Hz}, 1 \mathrm{H}), 3.21(\mathrm{t}, J=7.4 \mathrm{~Hz}, 2 \mathrm{H}), 2.21(\mathrm{~s}$, 1H) ppm; ${ }^{13} \mathrm{C}-\mathrm{NMR}\left(100 \mathrm{MHz}, \mathrm{CD}_{3} \mathrm{CN}\right) \delta 139.0,138.5,132.1,129.7,129.4,127.6,65.5$ (d, J = 7.6 Hz), $50.4,37.0 \mathrm{ppm}$.

Synthesis of 4-\{1,4-dioxaspiro[4.5]decan-2-yl\}-1H-1,2,3-triazole (20): to a stirred solution of 16 (1.0 eq) in a 1:1 mixture of $\mathrm{H}_{2} \mathrm{O} / t-\mathrm{BuOH}$, trimethylsilyl azide (10.0 eq), sodium ascorbate (0.5 eq) and $\mathrm{CuSO}_{4} \cdot 5 \mathrm{H}_{2} \mathrm{O}(5 \% \mathrm{~mol})$ were added. The reaction was stirred at room temperature overnight. The solvent was evaporated under reduced pressure, the crude was re-dissolved in EtOAc and extracted three times with water. The organic layer was dried over $\mathrm{MgSO}_{4}$, filtered and concentrated in vacuo. The crude was purified using CyH/TBME (3:1) as an eluent to yield 20 as a yellowish oil, 36\%, $R_{f}=0.61\left(\mathrm{CHCl}_{3} / \mathrm{MeOH} 9: 1\right)$, UHPLC-ESI-MS: $R_{t}=2.13, m / z=210.2[\mathrm{M}+\mathrm{H}]^{+} .{ }^{1} \mathrm{H}-\mathrm{NMR}(300 \mathrm{MHz}$, $\left.\mathrm{CD}_{3} \mathrm{CN}\right) \delta 7.72(\mathrm{~s}, 1 \mathrm{H}), 5.25(\mathrm{t}, J=6.6 \mathrm{~Hz}, 1 \mathrm{H}), 4.31-4.26(\mathrm{~m}, 1 \mathrm{H}), 4.00-3.95(\mathrm{~m}, 1 \mathrm{H}), 2.37(\mathrm{~s} b \mathrm{br}, 1 \mathrm{H})$, 1.64-1.58 (m, 8H), 1.43-1.40 (m, 2H) ppm; ${ }^{13} \mathrm{C}-\mathrm{NMR}\left(100 \mathrm{MHz}, \mathrm{CD}_{3} \mathrm{CN}\right) \delta 147.4,130.0,111.1,70.9,69.8$, $36.8,35.9,25.8,24.7,24.6 \mathrm{ppm}$. 
General procedure for the synthesis of $21 \mathrm{~h}-\mathbf{k}$ and $22 \mathrm{~h}-\mathrm{k}$ : to a stirred solution of 20 (1.0 eq) in dry THF, $\mathrm{K}_{2} \mathrm{CO}_{3}(2.0 \mathrm{eq})$ and the corresponding alkyl halide (bromide or iodide) were added. The reaction was stirred at reflux overnight. The solvent was evaporated under reduced pressure, the crude was re-dissolved in ACN (1 mL), filtered and purified by preparative HPLC.

For each compound, two different fractions were isolated corresponding to the 1,4- and 1,5-disubstitued products. The different substitution was determined by HMBC of two representative samples (21i, 22i).

General procedure for the synthesis of $18 \mathrm{~g}-\mathrm{k}$ and $19 \mathrm{~h}-\mathrm{k}$ : a stirred solution of 20 (or $21 \mathrm{~h}-\mathrm{k}$, or 22h-k) in 1,4-dioxane was cooled to $0{ }^{\circ} \mathrm{C}$ using an ice bath. A catalytic amount of $12 \mathrm{M} \mathrm{HCl}$ was added. The reaction was stirred at room temperature overnight. The solvent was evaporated under reduced pressure; the crude was re-dissolved in $\mathrm{Et}_{2} \mathrm{O}$ and extracted with water. The aqueous layer was extracted three times with $\mathrm{Et}_{2} \mathrm{O}$ and dried in vacuo to yield the corresponding products $18 \mathrm{~g}-\mathbf{k}$ and $19 \mathrm{~h}-\mathbf{k}$.

1-(1H-1,2,3-Triazol-4-yl)ethane-1,2-diol (18g): yellowish oil, 98\%, $R_{f}=0.13\left(\mathrm{CHCl}_{3} / \mathrm{MeOH}\right.$ 9:1), UHPLC-ESI-MS: $R_{t}=0.32, m / z=130.3[\mathrm{M}+\mathrm{H}]^{+} .{ }^{1} \mathrm{H}-\mathrm{NMR}(300 \mathrm{MHz}, \mathrm{MeOD}) \delta 8.38(\mathrm{~s}, 1 \mathrm{H}), 5.05(\mathrm{t}$, $J=5.5 \mathrm{~Hz}, 1 \mathrm{H}), 3.86-3.74(\mathrm{~m}, 2 \mathrm{H}) \mathrm{ppm} ;{ }^{13} \mathrm{C}-\mathrm{NMR}(100 \mathrm{MHz}, \mathrm{MeOD}) \delta$ 146.0, 126.4, 67.0, $66.2 \mathrm{ppm}$.

1-(1-Methyl-1H-1,2,3-triazol-4-yl)ethane-1,2-diol (18h): colorless oil, 66\%, $R_{f}=0.29\left(\mathrm{CHCl}_{3} / \mathrm{MeOH} 9: 1\right)$, UHPLC-ESI-MS: $R_{t}=0.45, m / z=144.2[\mathrm{M}+\mathrm{H}]^{+} .{ }^{1} \mathrm{H}-\mathrm{NMR}(300 \mathrm{MHz}, \mathrm{MeOD}) \delta 8.40(\mathrm{~s}, 1 \mathrm{H}), 5.04(\mathrm{t}$, $J=5.5 \mathrm{~Hz}, 1 \mathrm{H}), 4.35(\mathrm{~s}, 3 \mathrm{H}), 3.94-3.80(\mathrm{~m}, 2 \mathrm{H}) \mathrm{ppm} ;{ }^{13} \mathrm{C}-\mathrm{NMR}(100 \mathrm{MHz}, \mathrm{MeOD}) \delta 151.9,133.5,70.0$, $68.2,42.9 \mathrm{ppm}$.

1-(1-Methyl-1H-1,2,3-triazol-5-yl)ethane-1,2-diol (19h): colorless oil, $65 \%, R_{f}=0.32\left(\mathrm{CHCl}_{3} / \mathrm{MeOH} 9: 1\right)$, UHPLC-ESI-MS: $R_{t}=0.65, \mathrm{~m} / z=144.1[\mathrm{M}+\mathrm{H}]^{+} .{ }^{1} \mathrm{H}-\mathrm{NMR}(300 \mathrm{MHz}, \mathrm{MeOD}) \delta 7.60(\mathrm{~s}, 1 \mathrm{H}), 4.81(\mathrm{dd}$, $J=4.8 \mathrm{~Hz}, J=6.8 \mathrm{~Hz}, 1 \mathrm{H}), 4.13(\mathrm{~s}, 3 \mathrm{H}), 3.81-3.68(\mathrm{~m}, 2 \mathrm{H}) \mathrm{ppm} ;{ }^{13} \mathrm{C}-\mathrm{NMR}(100 \mathrm{MHz}, \mathrm{MeOD}) \delta 150.6$, $133.4,68.7,67.0,41.7 \mathrm{ppm}$.

1-[1-(Cyclopropylmethyl)-1H-1,2,3-triazol-4-yl]ethane-1,2-diol (18i): colorless oil, 73\%, $R_{f}=0.32$ $\left(\mathrm{CHCl}_{3} / \mathrm{MeOH}\right.$ 9:1), UHPLC-ESI-MS: $R_{t}=1.25, m / z=184.2[\mathrm{M}+\mathrm{H}]^{+} .{ }^{1} \mathrm{H}-\mathrm{NMR}\left(300 \mathrm{MHz}, \mathrm{CD}_{3} \mathrm{CN}\right)$ $\delta 8.29(\mathrm{~d}, J=9.1 \mathrm{~Hz}, 1 \mathrm{H}), 6.21(\mathrm{~s} \mathrm{br}, 2 \mathrm{H}), 5.02(\mathrm{dd}, J=3.9 \mathrm{~Hz}, J=6.4 \mathrm{~Hz}, 1 \mathrm{H}), 4.36(\mathrm{dd}, J=2.5 \mathrm{~Hz}$, $J=7.4 \mathrm{~Hz}, 2 \mathrm{H}), 3.80(\mathrm{~d}, J=5.3 \mathrm{~Hz}, 2 \mathrm{H}), 1.40-1.35(\mathrm{~m}, 1 \mathrm{H}), 0.70-0.64(\mathrm{~m}, 2 \mathrm{H}), 0.52-0.47(\mathrm{~m}, 2 \mathrm{H}) \mathrm{ppm}$; ${ }^{13} \mathrm{C}-\mathrm{NMR}\left(100 \mathrm{MHz}, \mathrm{CD}_{3} \mathrm{CN}\right) \delta 146.8,125.8,66.9,65.7,57.8,11.1,4.5 \mathrm{ppm}$.

1-[1-(Cyclopropylmethyl)-1H-1,2,3-triazol-5-yl]ethane-1,2-diol (19i): colorless oil, 77\%, $R_{f}=0.35$ $\left(\mathrm{CHCl}_{3} / \mathrm{MeOH} 9: 1\right)$, UHPLC-ESI-MS: $R_{t}=1.31, m / z=184.2[\mathrm{M}+\mathrm{H}]^{+} .{ }^{1} \mathrm{H}-\mathrm{NMR}\left(300 \mathrm{MHz}, \mathrm{CD}_{3} \mathrm{CN}\right) \delta$ $7.87(\mathrm{~s}, 1 \mathrm{H}), 4.91(\mathrm{t}, J=5.5 \mathrm{~Hz}, 1 \mathrm{H}), 4.34(\mathrm{~d}, J=7.3 \mathrm{~Hz}, 2 \mathrm{H}), 3.76(\mathrm{~d}, J=5.5 \mathrm{~Hz}, 2 \mathrm{H}), 1.43-1.38(\mathrm{~m}, 1 \mathrm{H})$, 0.64-0.58 (m, 2H), 0.49-0.46 (m, 2H) ppm; ${ }^{13} \mathrm{C}-\mathrm{NMR}\left(100 \mathrm{MHz}, \mathrm{CD}_{3} \mathrm{CN}\right) \delta 140.3,130.7,65.5,65.4,55.2$, $11.7,4.6 \mathrm{ppm}$.

1-(1-Butyl-1H-1,2,3-triazol-4-yl)ethane-1,2-diol (18j): colorless oil, 85\%, $R_{f}=0.37\left(\mathrm{CHCl}_{3} / \mathrm{MeOH}\right.$ 9:1), UHPLC-ESI-MS: $R_{t}=1.45, m / z=186.2[\mathrm{M}+\mathrm{H}]^{+} .{ }^{1} \mathrm{H}-\mathrm{NMR}(300 \mathrm{MHz}, \mathrm{MeOD}) \delta 8.28(\mathrm{~s}, 1 \mathrm{H}), 4.77(\mathrm{t}$, $J=5.5 \mathrm{~Hz}, 1 \mathrm{H}), 4.39(\mathrm{t}, J=7.2 \mathrm{~Hz}, 2 \mathrm{H}), 3.63-3.49(\mathrm{~m}, 2 \mathrm{H}), 1.81-1.71(\mathrm{~m}, 2 \mathrm{H}), 1.23-1.11(\mathrm{~m}, 2 \mathrm{H}), 0.76(\mathrm{t}$, $J=7.4 \mathrm{~Hz}, 3 \mathrm{H}) \mathrm{ppm} ;{ }^{13} \mathrm{C}-\mathrm{NMR}(100 \mathrm{MHz}, \mathrm{MeOD}) \delta 147.5,126.7,67.2,66.1,53.8,32.6,20.5,13.7$ ppm.

1-(1-Butyl-1H-1,2,3-triazol-5-yl)ethane-1,2-diol (19j): colorless oil, 95\%, $R_{f}=0.39\left(\mathrm{CHCl}_{3} / \mathrm{MeOH} 9: 1\right)$, UHPLC-ESI-MS: $R_{t}=1.50, m / z=186.2[\mathrm{M}+\mathrm{H}]^{+} .{ }^{1} \mathrm{H}-\mathrm{NMR}(300 \mathrm{MHz}, \mathrm{MeOD}) \delta 8.21(\mathrm{~s}, 1 \mathrm{H}), 4.98(\mathrm{t}$, $J=5.7 \mathrm{~Hz}, 1 \mathrm{H}), 4.62(\mathrm{dd}, J=6.5 \mathrm{~Hz}, J=8.4 \mathrm{~Hz}, 2 \mathrm{H}), 3.91-3.78(\mathrm{~m}, 2 \mathrm{H}), 2.04-1.94(\mathrm{~m}, 2 \mathrm{H}), 1.49-1.37(\mathrm{~m}$, 2H), 1.00 (t, $J=7.3 \mathrm{~Hz}, 3 \mathrm{H}) \mathrm{ppm} ;{ }^{13} \mathrm{C}-\mathrm{NMR}(100 \mathrm{MHz}, \mathrm{MeOD}) \delta 142.7,130.1,65.9,65.8,51.5,32.8,20.7$, $13.8 \mathrm{ppm}$. 
1-[1-(2-Ethoxyethyl)-1H-1,2,3-triazol-4-yl]ethane-1,2-diol (18k): colorless oil, 91\%, $R_{f}=0.31$ $\left(\mathrm{CHCl}_{3} / \mathrm{MeOH} 9: 1\right)$, UHPLC-ESI-MS: $R_{t}=1.21, m / z=202.2[\mathrm{M}+\mathrm{H}]^{+} .{ }^{1} \mathrm{H}-\mathrm{NMR}\left(300 \mathrm{MHz}, \mathrm{CD}_{3} \mathrm{CN}\right) \delta$ $7.92(\mathrm{~s}, 1 \mathrm{H}), 4.89(\mathrm{t}, J=5.1 \mathrm{~Hz}, 1 \mathrm{H}), 4.54(\mathrm{t}, J=5.1 \mathrm{~Hz}, 2 \mathrm{H}), 3.83-3.68(\mathrm{~m}, 4 \mathrm{H}), 3.47(\mathrm{q}, J=7.0 \mathrm{~Hz}, 2 \mathrm{H})$, $1.10(\mathrm{t}, J=7.0 \mathrm{~Hz}, 3 \mathrm{H}) \mathrm{ppm} ;{ }^{13} \mathrm{C}-\mathrm{NMR}\left(100 \mathrm{MHz}, \mathrm{CD}_{3} \mathrm{CN}\right) \delta 148.3,124.9,68.8,67.7,66.9,66.3,52.1$, 15.2 ppm.

1-[1-(2-Ethoxyethyl)-1H-1,2,3-triazol-4-yl]ethane-1,2-diol (19k): colorless oil, 82\%, $R_{f}=0.37$ $\left(\mathrm{CHCl}_{3} / \mathrm{MeOH} 9: 1\right)$, UHPLC-ESI-MS: $R_{t}=1.23, m / z=202.2[\mathrm{M}+\mathrm{H}]^{+} .{ }^{1} \mathrm{H}-\mathrm{NMR}(300 \mathrm{MHz}, \mathrm{MeOD}) \delta$ $8.10(\mathrm{~s}, 1 \mathrm{H}), 5.00(\mathrm{t}, J=5.5 \mathrm{~Hz}, 1 \mathrm{H}), 4.74(\mathrm{dd}, J=3.7 \mathrm{~Hz}, J=5.3 \mathrm{~Hz}, 2 \mathrm{H}), 3.84(\mathrm{t}, J=5.2 \mathrm{~Hz}, 2 \mathrm{H}), 3.77(\mathrm{t}$, $J=5.8 \mathrm{~Hz}, 2 \mathrm{H}), 3.46-3.38(\mathrm{~m}, 2 \mathrm{H}), 1.05(\mathrm{t}, J=7.0 \mathrm{~Hz}, 3 \mathrm{H}) \mathrm{ppm} ;{ }^{13} \mathrm{C}-\mathrm{NMR}(100 \mathrm{MHz}, \mathrm{MeOD}) \delta 143.4$, $130.3,69.6,67.7,66.0,65.9,51.7,15.3 \mathrm{ppm}$.

\subsection{General Procedures for the Synthesis of 3,5-Disubstituted Isoxazoles DPD Derivatives (Series III and IV)}

General procedure for the synthesis of 241-r: to a stirred solution of the corresponding aldehyde (1.0 eq) in $\mathrm{EtOH}(10 \mathrm{~mL}), \mathrm{Et}_{3} \mathrm{~N}(1.5 \mathrm{eq})$ and $\mathrm{NH}_{2} \mathrm{OH}^{*} \mathrm{HCl}(1.5 \mathrm{eq})$ dissolved in water $(10 \mathrm{~mL})$ were added. The reaction was stirred at room temperature for 1-3 hours (monitored by TLC). The solvent was evaporated under reduced pressure; the crude was re-dissolved in EtOAc and extracted three times with water. The organic layer was dried over $\mathrm{MgSO}_{4}$, filtered and concentrated in vacuo to yield the corresponding oxime. All the resulting compounds were used in the next step without being purified.

General procedure for the synthesis of 251-r: to a stirred solution of the corresponding oxime (1.0 eq) in DMF, $N$-chlorosuccinimide (1.0 eq) was added in two portions. The reaction was stirred at room temperature for 1-2 h (monitored by TLC). The crude was diluted with $\mathrm{Et}_{2} \mathrm{O}$ and extracted five times with water and once with brine. The organic layer was dried over $\mathrm{MgSO}_{4}$, filtered and concentrated in vacuo to yield the corresponding chloro-oxime. All the resulting compounds were used in the next step without being purified.

General procedure for the synthesis of 261-r: to a stirred solution of $\mathbf{1 5}$ (1.0 eq) in a 1:1 mixture of $\mathrm{H}_{2} \mathrm{O} / \mathrm{t}$ - $\mathrm{BuOH}$, the corresponding chloro-oxime (1.0 eq), sodium ascorbate $(0.5 \mathrm{eq}), \mathrm{CuSO}_{4} \cdot 5 \mathrm{H}_{2} \mathrm{O}$ $(5 \% \mathrm{~mol})$ and $\mathrm{KHCO}_{3}(4.3 \mathrm{eq})$ were added. The mixture was stirred at room temperature overnight. The solvent was evaporated under reduced pressure; the crude was redissolved in $\mathrm{ACN}(1 \mathrm{~mL})$, filtered and purified by preparative HPLC [49].

1-[3-(4-Methylphenyl)-1,2-oxazol-5-yl]ethane-1,2-diol (261): white solid, 82\%, $R_{f}=0.38\left(\mathrm{CHCl}_{3} / \mathrm{MeOH} 9: 1\right)$, UHPLC-ESI-MS: $R_{t}=2.15, m / z=220.1[\mathrm{M}+\mathrm{H}]^{+} .{ }^{1} \mathrm{H}-\mathrm{NMR}\left(300 \mathrm{MHz}, \mathrm{CD}_{3} \mathrm{CN}\right) \delta 7.73(\mathrm{~d}, J=8.0 \mathrm{~Hz}$, $2 \mathrm{H}), 7.31(\mathrm{~d}, J=7.9 \mathrm{~Hz}, 2 \mathrm{H}), 6.67(\mathrm{~s}, 1 \mathrm{H}), 4.82(\mathrm{~d}, J=5.2 \mathrm{~Hz}, 1 \mathrm{H}), 3.92$ (s br, 1H), 3.83-3.71 (m, 2H), 3.14 (s br, 1H), 2.38 (s, 3H) ppm; ${ }^{13} \mathrm{C}-\mathrm{NMR}\left(100 \mathrm{MHz}, \mathrm{CD}_{3} \mathrm{CN}\right) \delta 175.3,163.7,142.0,131.3,128.2,127.9$, $101.2,69.2,66.0,22.0 \mathrm{ppm}$.

1-[3-(3-Chlorophenyl)-1,2-oxazol-5-yl]ethane-1,2-diol (26m): white solid, 87\%, $R_{f}=0.51\left(\mathrm{CHCl}_{3} / \mathrm{MeOH}\right.$ 9:1), UHPLC-ESI-MS: $R_{t}=2.24, m / z=240.0[\mathrm{M}+\mathrm{H}]^{+} .{ }^{1} \mathrm{H}-\mathrm{NMR}\left(300 \mathrm{MHz}, \mathrm{CD}_{3} \mathrm{CN}\right) \delta 7.87(\mathrm{~s}, 1 \mathrm{H})$, $7.77(\mathrm{dd}, J=5.4 \mathrm{~Hz}, J=6.8 \mathrm{~Hz}, 1 \mathrm{H}), 7.48(\mathrm{~d}, J=5.8 \mathrm{~Hz}, 2 \mathrm{H}), 6.74(\mathrm{~s}, 1 \mathrm{H}), 4.84(\mathrm{t}, J=5.3 \mathrm{~Hz}, 1 \mathrm{H}), 3.78(\mathrm{dq}$, $J=5.3 \mathrm{~Hz}, J=11.4 \mathrm{~Hz}, 2 \mathrm{H}) \mathrm{ppm} ;{ }^{13} \mathrm{C}-\mathrm{NMR}\left(100 \mathrm{MHz}, \mathrm{CD}_{3} \mathrm{CN}\right) \delta 175.2,162.0,135.4,132.0,131.6,130.9$, $127.5,126.1,100.8,68.5,65.2 \mathrm{ppm}$.

1-[3-(2,4-Difluorophenyl)-1,2-oxazol-5-yl]ethane-1,2-diol (26n): white solid, 78\%, $R_{f}=0.49\left(\mathrm{CHCl}_{3} / \mathrm{MeOH}\right.$ 9:1), UHPLC-ESI-MS: $R_{t}=2.06, m / z=242.2[\mathrm{M}+\mathrm{H}]^{+} .{ }^{1} \mathrm{H}-\mathrm{NMR}\left(300 \mathrm{MHz}, \mathrm{CD}_{3} \mathrm{CN}\right) \delta 7.97-7.89(\mathrm{~m}$, 1H), 7.14-7.06 (m, 2H), $6.69(\mathrm{~d}, J=3.3 \mathrm{~Hz}, 1 \mathrm{H}), 4.86(\mathrm{t}, J=5.3 \mathrm{~Hz}, 1 \mathrm{H}), 3.85-3.73(\mathrm{~m}, 2 \mathrm{H}) \mathrm{ppm} ;{ }^{13} \mathrm{C}-\mathrm{NMR}$ $\left(100 \mathrm{MHz}, \mathrm{CD}_{3} \mathrm{CN}\right) \delta 174.8,164.9(\mathrm{dd}, J=8.5 \mathrm{~Hz}, J=246.4 \mathrm{~Hz}), 161.4(\mathrm{dd}, J=8.5 \mathrm{~Hz}, J=249.4 \mathrm{~Hz}), 157.9$, $131.6(\mathrm{dd}, J=4.6 \mathrm{~Hz}, J=10.1 \mathrm{~Hz}), 114.7(\mathrm{dd}, J=3.9 \mathrm{~Hz}, J=12.6 \mathrm{~Hz}), 113.2(\mathrm{dd}, J=3.6 \mathrm{~Hz}, J=21.9 \mathrm{~Hz})$, $105.6(\mathrm{t}, J=26.1 \mathrm{~Hz}), 102.7(\mathrm{~d}, J=7.4 \mathrm{~Hz}), 68.5,65.3 \mathrm{ppm}$. 
1-[3-(Pyridin-3-yl)-1,2-oxazol-5-yl]ethane-1,2-diol (26o): orange solid, 71\%, $R_{f}=0.22\left(\mathrm{CHCl}_{3} / \mathrm{MeOH} 9: 1\right)$, UHPLC-ESI-MS: $R_{t}=1.14, m / z=207.2[\mathrm{M}+\mathrm{H}]^{+} .{ }^{1} \mathrm{H}-\mathrm{NMR}\left(300 \mathrm{MHz}, \mathrm{CD}_{3} \mathrm{CN}\right) \delta 9.04(\mathrm{~s}, 1 \mathrm{H}), 8.67(\mathrm{~s}$, $1 \mathrm{H}), 8.18(\mathrm{~d}, J=7.9 \mathrm{~Hz}, 1 \mathrm{H}), 7.46(\mathrm{dd}, J=5.3 \mathrm{~Hz}, J=7.2 \mathrm{~Hz}, 1 \mathrm{H}), 6.79(\mathrm{~s}, 1 \mathrm{H}), 4.87(\mathrm{t}, J=5.3 \mathrm{~Hz}, 1 \mathrm{H})$, 3.85-3.73 (m, 2H) ppm; ${ }^{13} \mathrm{C}-\mathrm{NMR}\left(100 \mathrm{MHz}, \mathrm{CD}_{3} \mathrm{CN}\right) \delta 175.4,160.9,151.9,148.7,135.0,126.2,124.9$, $100.7,68.5,65.3 \mathrm{ppm}$.

1-(3-Cyclopropyl-1,2-oxazol-5-yl)ethane-1,2-diol (26p): yellow oil, 63\%, $R_{f}=0.12\left(\mathrm{CHCl}_{3} / \mathrm{MeOH}\right.$ 9:1), UHPLC-ESI-MS: $R_{t}=1.91, \mathrm{~m} / z=170.2[\mathrm{M}+\mathrm{H}]^{+} .{ }^{1} \mathrm{H}-\mathrm{NMR}\left(300 \mathrm{MHz}, \mathrm{CD}_{3} \mathrm{CN}\right) \delta 5.98(\mathrm{~s}, 1 \mathrm{H}), 4.71(\mathrm{ddd}$, $J=0.6 \mathrm{~Hz}, J=4.6 \mathrm{~Hz}, J=6.1 \mathrm{~Hz}, 1 \mathrm{H}), 3.74-3.62(\mathrm{~m}, 2 \mathrm{H}), 2.00-1.91(\mathrm{~m}, 1 \mathrm{H}), 1.03-0.97(\mathrm{~m}, 2 \mathrm{H}), 0.78-0.72$ (m, 2H) ppm; ${ }^{13} \mathrm{C}-\mathrm{NMR}\left(100 \mathrm{MHz}, \mathrm{CD}_{3} \mathrm{CN}\right) \delta 173.5,167.3,99.7,68.3,65.2,8.3,7.8 \mathrm{ppm}$.

1-[3-(Oxolan-3-yl)-1,2-oxazol-5-yl]ethane-1,2-diol (26q): yellow oil, 77\%, $R_{f}=0.50\left(\mathrm{CHCl}_{3} / \mathrm{MeOH} 9: 1\right)$, UHPLC-ESI-MS: $R_{t}=1.53, \mathrm{~m} / z=200.2[\mathrm{M}+\mathrm{H}]^{+} .{ }^{1} \mathrm{H}-\mathrm{NMR}\left(300 \mathrm{MHz}, \mathrm{CD}_{3} \mathrm{CN}\right) \delta 6.22(\mathrm{~s}, 1 \mathrm{H}), 4.77-4.73$ $(\mathrm{m}, 1 \mathrm{H}), 4.03-3.98(\mathrm{~m}, 1 \mathrm{H}), 3.94-3.85(\mathrm{~m}, 1 \mathrm{H}), 3.82-3.76(\mathrm{~m}, 1 \mathrm{H}), 3.74-3.65(\mathrm{~m}, 2 \mathrm{H}), 3.55-3.47(\mathrm{~m}, 1 \mathrm{H})$, 2.37-2.25 (m, 2H), 2.09-2.00 (m, 1H) ppm; ${ }^{13} \mathrm{C}-\mathrm{NMR}\left(100 \mathrm{MHz}, \mathrm{CD}_{3} \mathrm{CN}\right) \delta 174.1,166.1,101.2,72.7,68.5$, $65.3,63.7,37.4,32.5 \mathrm{ppm}$.

1-(3-Cyclohexyl-1,2-oxazol-5-yl)ethane-1,2-diol (26r): yellow oil, 89\%, $R_{f}=0.31\left(\mathrm{CHCl}_{3} / \mathrm{MeOH} 9: 1\right)$, UHPLC-ESI-MS: $R_{t}=2.13, m / z=212.2[\mathrm{M}+\mathrm{H}]^{+} .{ }^{1} \mathrm{H}-\mathrm{NMR}\left(300 \mathrm{MHz}, \mathrm{CD}_{3} \mathrm{CN}\right) \delta 6.18(\mathrm{~s}, 1 \mathrm{H}), 4.73(\mathrm{t}$, $J=5.4 \mathrm{~Hz}, 1 \mathrm{H}), 3.71(\mathrm{dq}, J=5.4 \mathrm{~Hz}, J=11.3 \mathrm{~Hz}, 2 \mathrm{H}), 2.70(\mathrm{dt}, J=3.3 \mathrm{~Hz}, J=10.7 \mathrm{~Hz}, 1 \mathrm{H}), 2.21(\mathrm{~s} \mathrm{br}$, 2H), 1.90-1.69 (m, 5H), 1.50-1.25 (m, 5H) ppm; ${ }^{13} \mathrm{C}-\mathrm{NMR}\left(100 \mathrm{MHz}, \mathrm{CD}_{3} \mathrm{CN}\right) \delta 173.9,169.8,101.5,69.2$, 66.0, 37.3, 33.4, 27.3, $27.2 \mathrm{ppm}$.

Synthesis of ethyl (2E)-2-(hydroxyimino)acetate (27): to a stirred solution of ethyl glyoxalate ( $50 \%$ solution in toluene, 1.0 eq) in $\mathrm{EtOH}_{,} \mathrm{Et}_{3} \mathrm{~N}$ (1.5 eq) and $\mathrm{NH}_{2} \mathrm{OH} \cdot \mathrm{HCl}$ (1.5 eq) dissolved in water $(10 \mathrm{~mL})$ were added. The reaction was stirred at room temperature for 2 hours (monitored by TLC). The solvent was evaporated under reduced pressure; the crude was re-dissolved in $\mathrm{Et}_{2} \mathrm{O}$ and extracted three times with water. The organic layer was dried over $\mathrm{MgSO}_{4}$, filtered and concentrated in vacuo to yield 27 as a colorless oil, $84 \%, R_{f}=0.64\left(\mathrm{CHCl}_{3} / \mathrm{MeOH} 9: 1\right) .{ }^{1} \mathrm{H}-\mathrm{NMR}\left(300 \mathrm{MHz}, \mathrm{CDCl}_{3}\right) \delta 9.83(\mathrm{~s} \mathrm{br}$, $1 \mathrm{H}), 7.56(\mathrm{~s}, 1 \mathrm{H}), 4.32(\mathrm{q}, J=7.1 \mathrm{~Hz}, 2 \mathrm{H}), 1.34(\mathrm{t}, J=7.1 \mathrm{~Hz}, 3 \mathrm{H}) \mathrm{ppm} ;{ }^{13} \mathrm{C}-\mathrm{NMR}\left(100 \mathrm{MHz}, \mathrm{CDCl}_{3}\right) \delta$ 162.4, 141.6, 61.8, $13.8 \mathrm{ppm}[60]$.

Synthesis of ethyl 5-\{1,4-dioxaspiro[4.5]decan-2-yl\}-1,2-oxazole-3-carboxylate (28): to a stirred solution of 16 (1.0 eq) in THF, 27 (2.0 eq) and $\mathrm{NaOCl}$ (40.0 eq portion wise over 12 hours) were added. The reaction was stirred at room temperature for 12 hours. The solvent was evaporated under reduced pressure, the crude was re-dissolved in DCM and washed three times with water. The organic layer was dried over $\mathrm{MgSO}_{4}$, filtered and concentrated in vacuo. The crude was re-dissolved in $\mathrm{ACN}(1 \mathrm{~mL})$, filtered and purified by preparative HPLC to yield 28 as a yellowish oil, 36\%, $R_{f}=0.57$ (CyH/EtOAC 3:1), UHPLC-ESI-MS: $R_{t}=3.04, m / z=282.2[\mathrm{M}+\mathrm{H}]^{+} .{ }^{1} \mathrm{H}-\mathrm{NMR}\left(300 \mathrm{MHz}, \mathrm{CDCl}_{3}\right) \delta 6.67(\mathrm{~s}, 1 \mathrm{H})$, $5.23(\mathrm{t}, J=6.0 \mathrm{~Hz}, 1 \mathrm{H}), 4.43(\mathrm{q}, J=7.2 \mathrm{~Hz}, 2 \mathrm{H}), 4.35(\mathrm{dd}, J=6.7 \mathrm{~Hz}, J=8.6 \mathrm{~Hz}, 1 \mathrm{H}), 4.09(\mathrm{dd}, J=5.4 \mathrm{~Hz}$, $J=8.6 \mathrm{~Hz}, 1 \mathrm{H}), 1.71-1.62(\mathrm{~m}, 9 \mathrm{H}), 1.41(\mathrm{t}, J=7.1 \mathrm{~Hz}, 4 \mathrm{H}) \mathrm{ppm} ;{ }^{13} \mathrm{C}-\mathrm{NMR}\left(100 \mathrm{MHz}, \mathrm{CDCl}_{3}\right) \delta 173.5$, $159.8,156.3,111.9,102.5,69.8,68.1,62.2,35.8,34.9,25.0,23.9,23.8,14.1$ ppm.

Synthesis of 5-\{1,4-dioxaspiro[4.5]decan-2-yl\}-1,2-oxazole-3-carboxylic acid (30): a stirred solution of 28 in THF was cooled to $0{ }^{\circ} \mathrm{C}$ using an ice bath. A solution of $10 \mathrm{M} \mathrm{NaOH}$ (5.0 eq) was added dropwise and the reaction was stirred at room temperature overnight. The solvent was evaporated under reduced pressure; the crude was re-dissolved in DCM and extracted with water. The aqueous layer was acidified with $1 \mathrm{M} \mathrm{HCl}$ until $\mathrm{pH}=1$ and extracted three times with $\mathrm{CHCl}_{3} / i-\mathrm{PrOH}$ (7:3). The organic layer was dried over $\mathrm{MgSO}_{4}$, filtered and concentrated in vacuo to yield $\mathbf{3 0}$ as a white solid, 99\%, $R_{f}=0.17\left(\mathrm{CHCl}_{3} / \mathrm{MeOH} 5: 1\right)$, UHPLC-ESI-MS: $R_{t}=2.37, m / z=254.2[\mathrm{M}+\mathrm{H}]{ }^{+} .{ }^{1} \mathrm{H}-\mathrm{NMR}$ $\left(300 \mathrm{MHz}, \mathrm{CDCl}_{3}\right) \delta 6.74(\mathrm{~s}, 1 \mathrm{H}), 5.26(\mathrm{t}, J=5.9 \mathrm{~Hz}, 1 \mathrm{H}), 4.38(\mathrm{dd}, J=6.6 \mathrm{~Hz}, J=8.7 \mathrm{~Hz}, 1 \mathrm{H}), 4.12(\mathrm{dd}$, $J=5.3 \mathrm{~Hz}, J=8.7 \mathrm{~Hz}, 1 \mathrm{H}), 1.73-1.60(\mathrm{~m}, 8 \mathrm{H}), 1.47-1.43(\mathrm{~m}, 2 \mathrm{H}) \mathrm{ppm} ;{ }^{13} \mathrm{C}-\mathrm{NMR}\left(100 \mathrm{MHz}, \mathrm{CDCl}_{3}\right) \delta$ $174.2,162.4,155.6,112.1,102.8,69.8,68.1,35.9,34.9,24.9,23.9,23.8$ ppm. 
General procedure for the synthesis of 32b, 32s-z: the reactions were performed in parallel in $15 \mathrm{~mL}$ reaction tubes in a 24 position Mettler-Toledo Miniblock®equipped with a heat transfer block and inert gas manifold. Each reaction tube was loaded with a previously prepared solution of $30 \mathrm{mg}$ of 28 (1.0 eq) in $2 \mathrm{~mL}$ of DMF, DIPEA (5.0 eq), HOBt (2.0 eq), EDC.HCl (2.5 eq). Then the corresponding amine was added (2.0 eq). The reaction mixtures were stirred at room temperature overnight. The reaction conversion was confirmed through a UHPLC check of some representative samples. The mixtures were evaporated until dryness. The crudes were re-dissolved in $1.0 \mathrm{~mL}$ of ACN, filtered and purified with preparative HPLC (gradient acetonitrile/water with $0.1 \%$ formic acid, $2-98 \%)$.

General procedure for the synthesis of $29,31,33 b, 33 s-z$ : a stirred solution of 28 (or 30 , or $\mathbf{3 2 b}$, or $32 \mathrm{~s}-\mathbf{z}$ ) was cooled to $0{ }^{\circ} \mathrm{C}$ using an ice bath. A catalytic amount of concentrated $\mathrm{HCl}$ was added. The reactions were stirred at room temperature overnight. The solvent was evaporated under reduced pressure, the crudes were re-dissolved in ACN (1 mL), filtered and purified by preparative HPLC.

Ethyl 5-(1,2-dihydroxyethyl)-1,2-oxazole-3-carboxylate (29): colorless oil, $46 \%, R_{f}=0.44\left(\mathrm{CHCl}_{3} / \mathrm{MeOH}\right.$ 9:1), UHPLC-ESI-MS: $R_{t}=1.51, m / z=202.2[\mathrm{M}+\mathrm{H}]^{+} .{ }^{1} \mathrm{H}-\mathrm{NMR}\left(300 \mathrm{MHz}, \mathrm{CD}_{3} \mathrm{CN}\right) \delta 6.65(\mathrm{~s}, 1 \mathrm{H})$, $4.84(\mathrm{t}, J=5.3 \mathrm{~Hz}, 1 \mathrm{H}), 4.37(\mathrm{q}, J=7.1 \mathrm{~Hz}, 2 \mathrm{H}), 3.76(\mathrm{dd}, J=4.2 \mathrm{~Hz}, J=5.2 \mathrm{~Hz}, 2 \mathrm{H}), 2.18(\mathrm{~s} \mathrm{br}, 1 \mathrm{H})$, $1.35(\mathrm{t}, J=7.1 \mathrm{~Hz}, 3 \mathrm{H}) \mathrm{ppm} ;{ }^{13} \mathrm{C}-\mathrm{NMR}\left(100 \mathrm{MHz}, \mathrm{CD}_{3} \mathrm{CN}\right) \delta 176.2,160.8,157.4,103.0,68.3,65.1,62.9$, $14.3 \mathrm{ppm}$.

5-(1,2-Dihydroxyethyl)-1,2-oxazole-3-carboxylic acid (31): colorless oil, 55\%, $R_{f}=0.11\left(\mathrm{CHCl}_{3} / \mathrm{MeOH} 9: 1\right)$, UHPLC-ESI-MS: $R_{t}=0.42, m / z=174.2[\mathrm{M}+\mathrm{H}]^{+} .{ }^{1} \mathrm{H}-\mathrm{NMR}\left(300 \mathrm{MHz}, \mathrm{CD}_{3} \mathrm{CN}\right) \delta 6.65(\mathrm{~s}, 1 \mathrm{H}), 4.84(\mathrm{t}$, $J=5.1 \mathrm{~Hz}, 1 \mathrm{H}), 3.81-3.70(\mathrm{~m}, 2 \mathrm{H}) \mathrm{ppm} ;{ }^{13} \mathrm{C}-\mathrm{NMR}\left(100 \mathrm{MHz}, \mathrm{CD}_{3} \mathrm{CN}\right) \delta 176.2,161.0,157.2,103.2,68.3$, $65.1 \mathrm{ppm}$.

N-Benzyl-5-(1,2-dihydroxyethyl)-1,2-oxazole-3-carboxamide (33b): white solid, 58\%, $R_{f}=0.25$ $\left(\mathrm{CHCl}_{3} / \mathrm{MeOH} 9: 1\right)$, UHPLC-ESI-MS: $R_{t}=1.89, m / z=263.2[\mathrm{M}+\mathrm{H}]^{+} .{ }^{1} \mathrm{H}-\mathrm{NMR}\left(300 \mathrm{MHz}\right.$, Acetone- $\left.d_{6}\right)$ 反 7.40-7.27 (m, 4H), 7.26-7.22 (m, 1H), $6.68(\mathrm{~s}, 1 \mathrm{H}), 4.91(\mathrm{t}, J=5.4 \mathrm{~Hz}, 1 \mathrm{H}), 4.59(\mathrm{~s}, 2 \mathrm{H}), 3.89-3.78(\mathrm{~m}$, 2H) ppm; ${ }^{13} \mathrm{C}-\mathrm{NMR}\left(100 \mathrm{MHz}\right.$, Acetone- $\left.d_{6}\right) \delta 177.2,160.6,141.0,137.3,130.2,129.4,128.9,102.9,69.5$, 66.4, 44.4 ppm.

5-(1,2-Dihydroxyethyl)-N-(4-fluorophenyl)-1,2-oxazole-3-carboxamide (33s): white solid, 58\%, $R_{f}=0.25$ $\left(\mathrm{CHCl}_{3} / \mathrm{MeOH} 9: 1\right)$, UHPLC-ESI-MS: $R_{t}=1.97, m / z=267.2[\mathrm{M}+\mathrm{H}]^{+} .{ }^{1} \mathrm{H}-\mathrm{NMR}\left(300 \mathrm{MHz}\right.$, Acetone- $\left.d_{6}\right)$ $\delta 7.92-7.88(\mathrm{~m}, 2 \mathrm{H}), 7.16(\mathrm{t}, J=8.8 \mathrm{~Hz}, 2 \mathrm{H}), 6.76(\mathrm{~s}, 1 \mathrm{H}), 4.95(\mathrm{t}, J=5.4 \mathrm{~Hz}, 1 \mathrm{H}), 3.92-3.81(\mathrm{~m}, 2 \mathrm{H}) \mathrm{ppm}$; ${ }^{13}$ C-NMR (100 MHz, Acetone- $\left.d_{6}\right) \delta 177.6,162.8,159.8(\mathrm{~d}, J=133.8 \mathrm{~Hz}), 159.6,136.3(\mathrm{~d}, J=2.7 \mathrm{~Hz})$, $124.1(\mathrm{~d}, J=7.7 \mathrm{~Hz}), 117.2(\mathrm{~d}, J=22.6 \mathrm{~Hz}), 103.1,69.5,66.4 \mathrm{ppm}$.

5-(1,2-Dihydroxyethyl)-N-[(thiophen-2-yl)methyl]-1,2-oxazole-3-carboxamide (33t): white solid, 65\%, $R_{f}=0.34\left(\mathrm{CHCl}_{3} / \mathrm{MeOH} 9: 1\right)$, UHPLC-ESI-MS: $R_{t}=1.79, m / z=269.2[\mathrm{M}+\mathrm{H}]^{+} .{ }^{1} \mathrm{H}-\mathrm{NMR}(300 \mathrm{MHz}$, Acetone- $\left.d_{6}\right) \delta 8.43(\mathrm{~s} \mathrm{br}, 0.5 \mathrm{H}), 7.32(\mathrm{dd}, J=1.3 \mathrm{~Hz}, J=5.1 \mathrm{~Hz}, 1 \mathrm{H}), 7.06(\mathrm{dd}, J=1.1 \mathrm{~Hz}, J=3.4 \mathrm{~Hz}, 1 \mathrm{H})$, $6.95(\mathrm{dd}, J=3.5 \mathrm{~Hz}, J=5.1 \mathrm{~Hz}, 1 \mathrm{H}), 6.68(\mathrm{~s}, 1 \mathrm{H}), 4.99(\mathrm{~s} \mathrm{br}, 0.5 \mathrm{H}), 4.90(\mathrm{t}, J=5.1 \mathrm{~Hz}, 1 \mathrm{H}), 4.77-4.75(\mathrm{~m}$, 2H), 4.15 (s br, 0.5H), 3.84-3.81 (m, 2H), 2.87 (s br, 0.5H) ppm; ${ }^{13} \mathrm{C}-\mathrm{NMR}\left(100 \mathrm{MHz}\right.$, Acetone- $\left.d_{6}\right) \delta 177.3$, $160.4,143.6,141.4,128.5,127.8,126.8,102.9,69.6,66.5,39.3$ ppm.

5-(1,2-Dihydroxyethyl)-N-[(pyridin-3-yl)methyl]-1,2-oxazole-3-carboxamide (33u): yellow oil, 37\%, $R_{f}=0.33$ $\left(\mathrm{CHCl}_{3} / \mathrm{MeOH} 9: 1\right)$, UHPLC-ESI-MS: $R_{t}=0.38, m / z=264.2[\mathrm{M}+\mathrm{H}]^{+} .{ }^{1} \mathrm{H}-\mathrm{NMR}(300 \mathrm{MHz}, \mathrm{MeOD}) \delta$ $8.56(\mathrm{~s}, 1 \mathrm{H}), 8.44(\mathrm{~s} \mathrm{br}, 1 \mathrm{H}), 7.86(\mathrm{~d}, J=7.9 \mathrm{~Hz}, 1 \mathrm{H}), 7.43(\mathrm{dd}, J=4.9 \mathrm{~Hz}, J=7.8 \mathrm{~Hz}, 1 \mathrm{H}), 6.70(\mathrm{~s}, 1 \mathrm{H})$, $4.84(\mathrm{~d}, J=5.8 \mathrm{~Hz}, 1 \mathrm{H}), 4.59(\mathrm{~s}, 1 \mathrm{H}), 3.80(\mathrm{dd}, J=3.3 \mathrm{~Hz}, J=5.6 \mathrm{~Hz}, 2 \mathrm{H}) \mathrm{ppm} ;{ }^{13} \mathrm{C}-\mathrm{NMR}(100 \mathrm{MHz}$, MeOD) $\delta 176.6,161.6,159.6,149.6,149.0,137.8,136.5,125.3,102.1,68.8,65.6,41.6$ ppm. 
5-(1,2-Dihydroxyethyl)-N-(2-methoxyethyl)-1,2-oxazole-3-carboxamide (33v): yellow oil, 78\%, $R_{f}=0.38$ $\left(\mathrm{CHCl}_{3} / \mathrm{MeOH} 9: 1\right)$, UHPLC-ESI-MS: $R_{t}=1.23, \mathrm{~m} / z=231.2[\mathrm{M}+\mathrm{H}]^{+} .{ }^{1} \mathrm{H}-\mathrm{NMR}\left(300 \mathrm{MHz}\right.$, Acetone- $\left.d_{6}\right)$ $\delta 6.64(\mathrm{~s}, 1 \mathrm{H}), 4.90(\mathrm{t}, J=5.4 \mathrm{~Hz}, 1 \mathrm{H}), 3.83(\mathrm{dd}, J=3.6 \mathrm{~Hz}, J=5.4 \mathrm{~Hz}, 2 \mathrm{H}), 3.58-3.50(\mathrm{~m}, 4 \mathrm{H}), 3.32(\mathrm{~s}, 3 \mathrm{H})$, 2.85 (s br, 2H) ppm; ${ }^{13} \mathrm{C}-\mathrm{NMR}\left(100 \mathrm{MHz}\right.$, Acetone- $\left.d_{6}\right) \delta 177.3,160.5,147.7,102.8,72.4,69.6,66.5,59.6$, $40.5 \mathrm{ppm}$.

1-[3-(Pyrrolidine-1-carbonyl)-1,2-oxazol-5-yl]ethane-1,2-diol (33z): yellow oil, $79 \%, \quad R_{f}=0.30$ $\left(\mathrm{CHCl}_{3} / \mathrm{MeOH} 9: 1\right)$, UHPLC-ESI-MS: $R_{t}=1.51, m / z=227.2[\mathrm{M}+\mathrm{H}]{ }^{+} .{ }^{1} \mathrm{H}-\mathrm{NMR}\left(300 \mathrm{MHz}\right.$, Acetone- $\left.d_{6}\right)$ $\delta 6.58(\mathrm{~s}, 1 \mathrm{H}), 4.90(\mathrm{t}, J=5.3 \mathrm{~Hz}, 1 \mathrm{H}), 3.83(\mathrm{t}, J=5.1 \mathrm{~Hz}, 2 \mathrm{H}), 3.76(\mathrm{t}, J=6.6 \mathrm{~Hz}, 2 \mathrm{H}), 3.54(\mathrm{t}, J=6.6 \mathrm{~Hz}$, 2H), $2.84(\mathrm{~s} \mathrm{br}, 2 \mathrm{H}), 1.99-1.89(\mathrm{~m}, 4 \mathrm{H}) \mathrm{ppm} ;{ }^{13} \mathrm{C}-\mathrm{NMR}\left(100 \mathrm{MHz}\right.$, Acetone- $\left.d_{6}\right) \delta 175.8,161.7,149.6,104.2$, 69.6, 66.6, 50.0, 48.2, 27.8, $25.5 \mathrm{ppm}$.

\subsection{Biology}

All chemicals were purchased from Sigma (Hamburg, Germany) if not otherwise stated. (S)-DPD was purchased from OMM Scientific (Dallas, TX, USA). The ATP Bioluminescence kit CLS II and Kinase Glo Luminescence assay kit were respectively purchased from Roche Scientific (Manheim, Germany) and Promega (Madison, WI, USA).

\subsubsection{LsrK Overexpression and Purification}

E. coli MET1158 (E. coli, amp resistance, BL21 (DE3) luxS-, with pMET1144 (lsrK-His in pET21b)), kindly donated by Prof. Karina Xavier (Instituto Gulbenkian de Ciência, Portugal) [61], was used for the overexpression of LsrK from S. typhimurium. The bacteria were grown overnight in $2 \times$ YPTG (yeast, tryptone, phosphate buffer and glucose) mediums supplemented with $100 \mu \mathrm{g} / \mathrm{mL}$ ampicillin. At the exponential phase, protein expression was induced by the addition of $0.1 \mathrm{mM}$ isopropyl $\beta$-D-1 thiogalactopyranoside for $9 \mathrm{~h}$ at $22{ }^{\circ} \mathrm{C}(250 \mathrm{rpm})$. Cells were harvested and frozen overnight before proceeding with lysis and purification, according to the literature [62].

\subsubsection{DPD Activity Evaluation}

Phosphorylation of DPD by LsrK was evaluated with a bioluminescence-based assay, ATP Bioluminescence kit CLSII (Roche) as previously described in Reference [61]. DPD was plated at $200 \mu \mathrm{M}$ and $400 \mu \mathrm{M}$ and a reaction mixture containing $200 \mathrm{nM}$ Lsrk and $20 \mu \mathrm{M}$ ATP in assay buffer ( $25 \mathrm{mM}$ triethanolamine, $\mathrm{pH} 7.4,200 \mu \mathrm{M} \mathrm{MgCl} 2$ ). Commercially available DPD was tested for comparison at $200 \mu \mathrm{M}$. The level of ATP was monitored by the ATP Bioluminescence kit CLSII following the manufacturer's instructions. The experiment was performed in the kinetic-mode, monitoring the luminescence every $2 \mathrm{~min}$ within a time window of $30 \mathrm{~min}$ at the Varioskan LUX plate reader (Thermo Fisher Scientific, Vantaa, Finland).

\subsubsection{Screening of DPD-Related Compounds}

The activity of DPD-related compounds was evaluated in an LsrK inhibition assay. Compounds were plated in a 384 well-plate to a final concentration of $200 \mu \mathrm{M}$ in triplicate. A $300 \mathrm{nM}$ LsrK and $300 \mu \mathrm{M}$ DPD diluted in an assay buffer ( $25 \mathrm{mM}$ triethanolamine, $\mathrm{pH} 7.4,200 \mu \mathrm{M} \mathrm{MgCl}_{2}, 0.1 \mathrm{mg} / \mathrm{mL}$ BSA) were added to the plate followed by $100 \mu \mathrm{M}$ ATP to start the reaction. After 15 min of reaction, the Kinase Glo Luminescence assay reagent was added according to the manufacturer's instructions. The experiment was carried on in end-point mode and the luminescence was recorded at the Varioskan LUX plate reader.

\section{Conclusions}

Resistance to antibiotics poses a continuous threat to public health. In the last few decades, receptors able to modulate QS started to be considered interesting targets for anti-infective therapy and the modulation/inhibition of QS has become an appealing strategy against bacterial resistance. 
Several studies have already shown that interference with QS affects biofilm formation and biofilm properties (e.g., thickness, mass). Particularly, DPD, the key compound in the biosynthesis of AI-2, is able to modulate QS in both Gram-negative and Gram-positive bacteria. Accordingly, DPD-analogs may have great potential as QSI and, therefore, as antimicrobial drugs. Of note, two different DPD-related compounds (i.e. isobutyl-DPD and phenyl-DPD) in combination with gentamicin have almost completely cleared the pre-existing biofilms in E. coli and P. aeruginosa, respectively [63].

In this work, we successfully developed a new short and robust strategy for the synthesis of DPD which requires only one purification step. Ph-DPD was also synthesized to show the applicability of our protocol to the production of different $C_{1}$-DPD analogs. The new strategy inspired the synthesis of 30 novel DPD-related compounds: the cycloaddition to two common precursors was employed to produce (in maximum four steps) four different small libraries where the diketo moiety of DPD was embedded in heteroaromatic rings. All the designed compounds were purified and characterized by ${ }^{1} \mathrm{H}-\mathrm{NMR},{ }^{13} \mathrm{C}-\mathrm{NMR}$, and UHPLC-MS (purity > 90\%). It is worth noting that in these compounds the open/closed equilibrium (typical of the majority of the DPD-analogs reported so far, Figure 1) is not possible. The so-obtained more stable compounds were easily purify by column chromatography. Moreover, the presence of heteroaromatic groups increases the UV absorbance and MW, rendering the compound detection by the classical analytical method (e.g., LC-MS) easier compared to previously reported analogs (e.g., ethyl-DPD).

Our new synthetic approach allowed us to synthetize a small set of racemic DPD-related compounds in a relatively easy and fast way. We demonstrated that racemic DPD is efficiently phosphorylated by LsrK, corroborating the validity of our approach. On the other hand, all compounds of our library of DPD-related did not show any activity on LsrK. Nevertheless, the synthetic procedure herein proposed might lead to the preparation of a wider compound library, thus, allowing for the discovery of a new class of LsrK inhibitors as potential antivirulence agents. Moreover, we decided to add these products to the library of MuTaLig, an innovative ligand identification platform for the drug-discovery process.

Supplementary Materials: Supplementary materials are available online.

Author Contributions: Conceptualization, S.S., F.G. and S.C.; Methodology, S.S., F.G.; Formal Analysis, F.M., M.P.; Investigation, S.S., V.G., M.P., F.G., S.C., P.T.; Resources, D.T., P.T.; Writing-Original Draft Preparation, S.S., V.G., P.T.; Writing-Review \& Editing, S.S., F.G., P.T., S.C.; Supervision, S.C.; Project Administration, A.K., D.T.; Funding Acquisition, F.G., D.T.

Funding: This research was funded by the European Union's Horizon 2020 research and innovation programme for funding INTEGRATE under the Marie Sklodowska Curie grant agreement $\mathrm{N}^{\circ} .642620$ and for the Marie Skłodowska-Curie Actions Individual Fellowship to SS.

Acknowledgments: Martyna Bielska, Xenia Iwanova, Virginia Llemos and Eduard Ackerman are acknowledged for technical assistance.

Conflicts of Interest: The authors declare no conflict of interest.

\section{References}

1. Surette, M.G.; Miller, M.B.; Bassler, B.L. Quorum sensing in Escherichia coli, Salmonella typhimurium, and Vibrio harveyi: A new family of genes responsible for autoinducer production. Proc. Natl. Acad. Sci. USA 1999, 96, 1639-1644. [CrossRef] [PubMed]

2. Waters, C.M.; Bassler, B.L. Quorum sensing: Cell-to-cell communication in bacteria. Annu. Rev. Cell Dev. Biol. 2005, 21, 319-346. [CrossRef] [PubMed]

3. Bassler, B.L.; Losick, R. Bacterially speaking. Cell 2006, 125, 237-246. [CrossRef] [PubMed]

4. Lowery, C.A.; Dickerson, T.J.; Janda, K.D. Interspecies and interkingdom communication mediated by bacterial quorum sensing. Chem. Soc. Rev. 2008, 37, 1337-1346. [CrossRef] [PubMed]

5. Ng, W.-L.; Bassler, B.L. Bacterial Quorum-Sensing Network Architectures. Annu. Rev. Genet. 2009, 43, 197-222. [CrossRef] [PubMed] 
6. Zhu, J.; Miller, M.B.; Vance, R.E.; Dziejman, M.; Bassler, B.L.; Mekalanos, J.J. Quorum-sensing regulators control virulence gene expression in Vibrio cholerae. Proc. Natl. Acad. Sci. USA 2002, 99, 3129-3134. [CrossRef] [PubMed]

7. Antunes, L.C.M.; Ferreira, R.B.R.; Buckner, M.M.C.; Finlay, B.B. Quorum sensing in bacterial virulence. Microbiology 2010, 156, 2271-2282. [CrossRef] [PubMed]

8. Ahmed, N.A.A.M.; Petersen, F.C.; Scheie, A.A. AI-2 quorum sensing affects antibiotic susceptibility in Streptococcus anginosus. J. Antimicrob. Chemother. 2007, 60, 49-53. [CrossRef] [PubMed]

9. Davies, D.G.; Parsek, M.R.; Pearson, J.P.; Iglewski, B.H.; Costerton, J.W.; Greenberg, E.P. The involvement of cell-to-cell signals in the development of a bacterial biofilm. Science 1998, 280, 295-298. [CrossRef] [PubMed]

10. Rickard, A.H.; Palmer, R.J.; Blehert, D.S.; Campagna, S.R.; Semmelhack, M.F.; Egland, P.G.; Bassler, B.L.; Kolenbrander, P.E. Autoinducer 2: A concentration-dependent signal for mutualistic bacterial biofilm growth. Mol. Microbiol. 2006, 60, 1446-1456. [CrossRef] [PubMed]

11. Irie, Y.; Parsek, M.R. Quorum sensing and microbial biofilms. Curr. Top. Microbiol. Immunol. 2008, 322, 67-84. [PubMed]

12. Smith, K.M.; Bu, Y.; Suga, H. Library screening for synthetic agonists and antagonists of a Pseudomonas aeruginosa autoinducer. Chem. Biol. 2003, 10, 563-571. [CrossRef]

13. Suga, H.; Smith, K.M. Molecular mechanisms of bacterial quorum sensing as a new drug target. Curr. Opin. Chem. Biol. 2003, 7, 586-591. [CrossRef] [PubMed]

14. Geske, G.D.; Wezeman, R.J.; Siegel, A.P.; Blackwell, H.E. Small Molecule Inhibitors of Bacterial Quorum Sensing and Biofilm Formation. J. Am. Chem. Soc. 2005, 127, 12762-12763. [CrossRef] [PubMed]

15. Rasmussen, T.B.; Givskov, M. Quorum-sensing inhibitors as anti-pathogenic drugs. Int. J. Med. Microbiol. 2006, 296, 149-161. [CrossRef] [PubMed]

16. Geske, G.D.; O’Neill, J.C.; Miller, D.M.; Mattmann, M.E.; Blackwell, H.E. Modulation of Bacterial Quorum Sensing with Synthetic Ligands: Systematic Evaluation of N-Acylated Homoserine Lactones in Multiple Species and New Insights into Their Mechanisms of Action. J. Am. Chem. Soc. 2007, 129, 13613-13625. [CrossRef] [PubMed]

17. Clatworthy, A.E.; Pierson, E.; Hung, D.T. Targeting virulence: A new paradigm for antimicrobial therapy. Nat. Chem. Biol. 2007, 3, 541-548. [CrossRef] [PubMed]

18. Meijler, M.M.; Hom, L.G.; Kaufmann, G.F.; McKenzie, K.M.; Sun, C.; Moss, J.A.; Matsushita, M.; Janda, K.D. Synthesis and Biological Validation of a Ubiquitous Quorum-Sensing Molecule. Angew. Chem. Int. Ed. 2004, 43, 2106-2108. [CrossRef] [PubMed]

19. Globisch, D.; Lowery, C.A.; McCague, K.C.; Janda, K.D. Uncharacterized 4,5-Dihydroxy-2,3-Pentanedione (DPD) Molecules Revealed ThrougH-NMR Spectroscopy: Implications for a Greater Signaling Diversity in Bacterial Species. Angew. Chem. Int. Ed. 2012, 51, 4204-4208. [CrossRef] [PubMed]

20. Chen, X.; Schauder, S.; Potier, N.; Van Dorsselaer, A.; Pelczer, I.; Bassler, B.L.; Hughson, F.M. Structural identification of a bacterial quorum-sensing signal containing boron. Nature 2002, 415, 545-549. [CrossRef] [PubMed]

21. Miller, S.T.; Xavier, K.B.; Campagna, S.R.; Taga, M.E.; Semmelhack, M.F.; Bassler, B.L.; Hughson, F.M. Salmonella typhimurium recognizes a chemically distinct form of the bacterial quorum-sensing signal AI-2. Mol. Cell 2004, 15, 677-687. [CrossRef] [PubMed]

22. Zhu, J.; Hixon, M.S.; Globisch, D.; Kaufmann, G.F.; Janda, K.D. Mechanistic Insights into the LsrK Kinase Required for Autoinducer-2 Quorum Sensing Activation. J. Am. Chem. Soc. 2013, 135, 7827-7830. [CrossRef] [PubMed]

23. Ha, J.-H.; Eo, Y.; Grishaev, A.; Guo, M.; Smith, J.A.I.; Sintim, H.O.; Kim, E.-H.; Cheong, H.-K.; Bentley, W.E.; Ryu, K.-S. Crystal Structures of the LsrR Proteins Complexed with Phospho-AI-2 and Two Signal-Interrupting Analogues Reveal Distinct Mechanisms for Ligand Recognition. J. Am. Chem. Soc. 2013, 135, 15526-15535. [CrossRef] [PubMed]

24. Penesyan, A.; Gillings, M.; Paulsen, I.T. Antibiotic discovery: Combatting bacterial resistance in cells and in biofilm communities. Mol. Basel Switz. 2015, 20, 5286-5298. [CrossRef] [PubMed]

25. Kociolek, M. Quorum-Sensing Inhibitors and Biofilms. Anti-Infect. Agents Med. Chem. 2009, 8, 315-326. [CrossRef]

26. Brackman, G.; Coenye, T. Quorum sensing inhibitors as anti-biofilm agents. Curr. Pharm. Des. 2015, $21,5-11$. [CrossRef] [PubMed] 
27. Xavier, K.B.; Bassler, B.L. Regulation of uptake and processing of the quorum-sensing autoinducer AI-2 in Escherichia coli. J. Bacteriol. 2005, 187, 238-248. [CrossRef] [PubMed]

28. Semmelhack, M.F.; Campagna, S.R.; Federle, M.J.; Bassler, B.L. An Expeditious Synthesis of DPD and Boron Binding Studies. Org. Lett. 2005, 7, 569-572. [CrossRef] [PubMed]

29. De Keersmaecker, S.C.J.; Varszegi, C.; van Boxel, N.; Habel, L.W.; Metzger, K.; Daniels, R.; Marchal, K.; De Vos, D.; Vanderleyden, J. Chemical synthesis of (S)-4,5-dihydroxy-2,3-pentanedione, a bacterial signal molecule precursor, and validation of its activity in Salmonella typhimurium. J. Biol. Chem. 2005, 280, 19563-19568. [CrossRef] [PubMed]

30. Lowery, C.A.; Park, J.; Kaufmann, G.F.; Janda, K.D. An Unexpected Switch in the Modulation of AI-2-Based Quorum Sensing Discovered through Synthetic 4,5-Dihydroxy-2,3-pentanedione Analogues. J. Am. Chem. Soc. 2008, 130, 9200-9201. [CrossRef] [PubMed]

31. Kadirvel, M.; Stimpson, W.T.; Moumene-Afifi, S.; Arsic, B.; Glynn, N.; Halliday, N.; Williams, P.; Gilbert, P.; McBain, A.J.; Freeman, S.; et al. Synthesis and bioluminescence-inducing properties of autoinducer (S)-4,5-dihydroxypentane-2,3-dione and its enantiomer. Bioorg. Med. Chem. Lett. 2010, 20, 2625-2628. [CrossRef] [PubMed]

32. Ascenso, O.S.; Marques, J.C.; Santos, A.R.; Xavier, K.B.; Rita Ventura, M.; Maycock, C.D. An efficient synthesis of the precursor of AI-2, the signalling molecule for inter-species quorum sensing. Bioorg. Med. Chem. 2011, 19, 1236-1241. [CrossRef] [PubMed]

33. Guo, M.; Gamby, S.; Zheng, Y.; Sintim, H. Small Molecule Inhibitors of AI-2 Signaling in Bacteria: State-of-the-Art and Future Perspectives for Anti-Quorum Sensing Agents. Int. J. Mol. Sci. 2013, 14, 17694-17728. [CrossRef] [PubMed]

34. Frezza, M.; Soulère, L.; Queneau, Y.; Doutheau, A. A Baylis-Hillman/ozonolysis route towards $( \pm)$ 4,5-dihydroxy-2,3-pentanedione (DPD) and analogues. Tetrahedron Lett. 2005, 46, 6495-6498. [CrossRef]

35. Smith, J.A.I.; Wang, J.; Nguyen-Mau, S.-M.; Lee, V.; Sintim, H.O. Biological screening of a diverse set of AI-2 analogues in Vibrio harveyi suggests that receptors which are involved in synergistic agonism of AI-2 and analogues are promiscuous. Chem. Commun. 2009, 45, 7033-7035. [CrossRef] [PubMed]

36. Rossi, D.; Tarantino, M.; Rossino, G.; Rui, M.; Juza, M.; Collina, S. Approaches for multi-gram scale isolation of enantiomers for drug discovery. Expert Opin. Drug Discov. 2017, 12, 1253-1269. [CrossRef] [PubMed]

37. Paterson, I.; Delgado, O.; Florence, G.J.; Lyothier, I.; O’Brien, M.; Scott, J.P.; Sereinig, N. A second-generation total synthesis of $(+)$-discodermolide: The development of a practical route using solely substrate-based stereocontrol. J. Org. Chem. 2005, 70, 150-160. [CrossRef] [PubMed]

38. Peyton, L.R.; Gallagher, S.; Hashemzadeh, M. Triazole antifungals: A review. Drugs Today Barc. Spain 1998 2015, 51, 705-718. [CrossRef]

39. Lal, K.; Yadav, P. Recent Advancements in 1,4-Disubstituted 1H-1,2,3-Triazoles as Potential Anticancer Agents. Anticancer Agents Med. Chem. 2018, 18, 21-37. [CrossRef] [PubMed]

40. Zhou, C.-H.; Wang, Y. Recent Researches in Triazole Compounds as Medicinal Drugs. Curr. Med. Chem. 2012, 19, 239-280. [CrossRef] [PubMed]

41. Haider, S.; Alam, M.S.; Hamid, H. 1,2,3-Triazoles: Scaffold with medicinal significance. Inflamm. Cell Signal. 2014, 1. [CrossRef]

42. Keri, R.S.; Patil, S.A.; Budagumpi, S.; Nagaraja, B.M. Triazole: A Promising Antitubercular Agent. Chem. Biol. Drug Des. 2015, 86, 410-423. [CrossRef] [PubMed]

43. Kharb, R.; Shahar Yar, M.; Sharma, P.C. Recent advances and future perspectives of triazole analogs as promising antiviral agents. Mini Rev. Med. Chem. 2011, 11, 84-96. [CrossRef] [PubMed]

44. MacDonald, J.P.; Badillo, J.J.; Arevalo, G.E.; Silva-García, A.; Franz, A.K. Catalytic Stereoselective Synthesis of Diverse Oxindoles and Spirooxindoles from Isatins. ACS Comb. Sci. 2012, 14, 285-293. [CrossRef] [PubMed]

45. Nolte, C.; Mayer, P.; Straub, B.F. Isolation of a copper(I) triazolide: A “click" intermediate. Angew. Chem. Int. Ed. 2007, 46, 2101-2103. [CrossRef] [PubMed]

46. Shao, C.; Wang, X.; Xu, J.; Zhao, J.; Zhang, Q.; Hu, Y. Carboxylic Acid-Promoted Copper(I)-Catalyzed Azide-Alkyne Cycloaddition. J. Org. Chem. 2010, 75, 7002-7005. [CrossRef] [PubMed]

47. Shao, C.; Cheng, G.; Su, D.; Xu, J.; Wang, X.; Hu, Y. Copper(I) Acetate: A Structurally Simple but Highly Efficient Dinuclear Catalyst for Copper-Catalyzed Azide-Alkyne Cycloaddition. Adv. Synth. Catal. 2010, 352, 1587-1592. [CrossRef] 
48. Shao, C.; Wang, X.; Zhang, Q.; Luo, S.; Zhao, J.; Hu, Y. Acid-Base Jointly Promoted Copper(I)-Catalyzed Azide-Alkyne Cycloaddition. J. Org. Chem. 2011, 76, 6832-6836. [CrossRef] [PubMed]

49. Himo, F.; Lovell, T.; Hilgraf, R.; Rostovtsev, V.V.; Noodleman, L.; Sharpless, K.B.; Fokin, V.V. Copper(I)-Catalyzed Synthesis of Azoles. DFT Study Predicts Unprecedented Reactivity and Intermediates. J. Am. Chem. Soc. 2005, 127, 210-216. [CrossRef] [PubMed]

50. Boren, B.C.; Narayan, S.; Rasmussen, L.K.; Zhang, L.; Zhao, H.; Lin, Z.; Jia, G.; Fokin, V.V. Ruthenium-catalyzed azide-alkyne cycloaddition: Scope and mechanism. J. Am. Chem. Soc. 2008, 130, 8923-8930. [CrossRef] [PubMed]

51. Cecchi, L.; De Sarlo, F.; Machetti, F. 1,4-Diazabicyclo[2.2.2]octane (DABCO) as an Efficient Reagent for the Synthesis of Isoxazole Derivatives from Primary Nitro Compounds and Dipolarophiles: The Role of the Base. Eur. J. Org. Chem. 2006, 2006, 4852-4860. [CrossRef]

52. Chand, P.; Kotian, P.L.; Dehghani, A.; El-Kattan, Y.; Lin, T.-H.; Hutchison, T.L.; Babu, Y.S.; Bantia, S.; Elliott, A.J.; Montgomery, J.A. Systematic Structure-Based Design and Stereoselective Synthesis of Novel Multisubstituted Cyclopentane Derivatives with Potent Antiinfluenza Activity. J. Med. Chem. 2001, 44, 4379-4392. [CrossRef] [PubMed]

53. Jones, P.; Atack, J.R.; Braun, M.P.; Cato, B.P.; Chambers, M.S.; O'Connor, D.; Cook, S.M.; Hobbs, S.C.; Maxey, R.; Szekeres, H.J.; et al. Pharmacokinetics and metabolism studies on (3-tert-butyl-7-(5methylisoxazol-3-yl)-2-(1-methyl-1H-1,2,4-triazol-5-ylmethoxy) pyrazolo[1,5-d][1,2,4]triazine, a functionally selective GABAA $\alpha 5$ inverse agonist for cognitive dysfunction. Bioorg. Med. Chem. Lett. 2006, 16, 872-875. [CrossRef] [PubMed]

54. Quan, M.L.; Liauw, A.Y.; Ellis, C.D.; Pruitt, J.R.; Carini, D.J.; Bostrom, L.L.; Huang, P.P.; Harrison, K.; Knabb, R.M.; Thoolen, M.J.; et al. Design and Synthesis of Isoxazoline Derivatives as Factor Xa Inhibitors. 1. J. Med. Chem. 1999, 42, 2752-2759. [CrossRef] [PubMed]

55. Mohamed, Y.A.M.; Inagaki, F.; Takahashi, R.; Mukai, C. A new procedure for the preparation of 2-vinylindoles and their [4+2] cycloaddition reaction. Tetrahedron 2011, 67, 5133-5141. [CrossRef]

56. Aponick, A.; Li, C.-Y.; Malinge, J.; Marques, E.F. An Extremely Facile Synthesis of Furans, Pyrroles, and Thiophenes by the Dehydrative Cyclization of Propargyl Alcohols. Org. Lett. 2009, 11, 4624-4627. [CrossRef] [PubMed]

57. Gamby, S.; Roy, V.; Guo, M.; Smith, J.A.I.; Wang, J.; Stewart, J.E.; Wang, X.; Bentley, W.E.; Sintim, H.O. Altering the communication networks of multispecies microbial systems using a diverse toolbox of AI-2 analogues. ACS Chem. Biol. 2012, 7, 1023-1030. [CrossRef] [PubMed]

58. Morriello, G.; Devita, R.; Mills, S.; Moyes, C.; Lin, P. Anti-Hypercholesterolemic Compounds 2010. U.S. Patent 20070078098A1, 5 April 2007.

59. Mames, A.; Stecko, S.; Mikołajczyk, P.; Soluch, M.; Furman, B.; Chmielewski, M. Direct, Catalytic Synthesis of Carbapenams via Cycloaddition/Rearrangement Cascade Reaction: Unexpected Acetylenes' Structure Effect. J. Org. Chem. 2010, 75, 7580-7587. [CrossRef] [PubMed]

60. Jen, T.; Mendelsohn, B.A.; Ciufolini, M.A. Oxidation of $\alpha$-Oxo-Oximes to Nitrile Oxides with Hypervalent Iodine Reagents. J. Org. Chem. 2011, 76, 728-731. [CrossRef] [PubMed]

61. Xavier, K.B.; Miller, S.T.; Lu, W.; Kim, J.H.; Rabinowitz, J.; Pelczer, I.; Semmelhack, M.F.; Bassler, B.L. Phosphorylation and Processing of the Quorum-Sensing Molecule Autoinducer-2 in Enteric Bacteria. ACS Chem. Biol. 2007, 2, 128-136. [CrossRef] [PubMed]

62. Tsuchikama, K.; Zhu, J.; Lowery, C.A.; Kaufmann, G.F.; Janda, K.D. C4-Alkoxy-HPD: A Potent Class of Synthetic Modulators Surpassing Nature in AI-2 Quorum Sensing. J. Am. Chem. Soc. 2012, 134, 13562-13564. [CrossRef] [PubMed]

63. Roy, V.; Meyer, M.T.; Smith, J.A.I.; Gamby, S.; Sintim, H.O.; Ghodssi, R.; Bentley, W.E. AI-2 analogs and antibiotics: A synergistic approach to reduce bacterial biofilms. Appl. Microbiol. Biotechnol. 2013, 97, 2627-2638. [CrossRef] [PubMed]

Sample Availability: Samples of the compounds are all available from the authors. 